\title{
RFD
}

\section{IGUALDADE DE GÊNERO E DIREITOS SOCIAIS NO CONTEXTO DO ESTADO \\ CONSTITUCIONAL DE DIREITO}

\author{
GENDER EQUALITY AND SOCIAL RIGHT IN THE CONTEXT OF THE \\ CONSTITUTIONAL RULE OF LAW
}

Bernardo Brasil Campinho. ${ }^{1}$

\begin{abstract}
Resumo: Este trabalho tem por objetivo analisar como a formulação e aplicação de direitos sociais, trabalhistas ou prestacionais, se relacionam com as pretensões de igualdade de gênero que emergem nas intersecções contemporâneas entre Estado de Direito, constitucionalismo e democracia, particularmente no contexto brasileiro. A busca pela compreensão das conexões entre direitos sociais e igualdade de gênero deve necessariamente se ater ao papel mediador que a noção de Estado de Direito exerce quanto à dicotomia universalidade/singularidade (igualdade/diferença), bem como deve buscar analisar como as diferentes funções realizadas pelos direitos humanos e fundamentais atuam neste processo de afirmação da igualdade de gênero. Neste sentido, os direitos sociais exercem um papel importante na promoção não apenas de reconhecimento, mas da inclusão como efetivação do mesmo, e como base mesmo para a construção da participação política.
\end{abstract}

Palavras-chave: Igualdade de gênero. Direitos sociais. Estado Constitucional de Direito.

Abstract: This study aims to analyze how the formulation and application of social rights relate to gender equality claims that emerge in contemporary intersections between rule of law, constitutionalism and democracy, particularly in the Brazilian context. The search for understanding of the connections between social rights and gender equality must necessarily stick to the mediating role that the notion of rule of law plays on the dichotomy universality / uniqueness (equality / difference), and should seek to analyze how the different functions performed by fundamental and human rights work in this process of affirmation of gender equality. In this sense, social rights play an important role in promoting not only recognition, but the inclusion as a realization of the same, and even as the basis for building political participation.

Keywords: Gender equality. Social rights. Constitutional rule of law.

\footnotetext{
${ }^{1}$ Advogado. Bacharel em Direito pela Universidade Federal da Bahia (UFBA). Mestre e Doutor em Direito pela Universidade do Estado do Rio de Janeiro (UERJ). Professor Adjunto do Departamento de Ciências Jurídicas do Instituto Multidisciplinar da Universidade Federal do Rio de Janeiro (UFRRJ). Professor Auxiliar da Universidade Estácio de Sá (UNESA).
}

Artigo recebido em 05/06/2016 e aprovado para publicação em 13/02/2019. 


\section{RFD}

\section{INTRODUÇÃO}

Este trabalho tem por objetivo analisar como a formulação e aplicação de direitos sociais, trabalhistas ou prestacionais, se relacionam com as pretensões de igualdade de gênero que emergem nas intersecções contemporâneas entre Estado de Direito, constitucionalismo e democracia, particularmente no contexto brasileiro.

A trajetória de afirmação do princípio do Estado de Direito às relações de gênero e até este momento foram vistas sob a perspectiva da não discriminação como meio para o reconhecimento, tanto ético quanto político. Direitos iguais para cidadãos e cidadãs iguais.

Para além dos direitos civis, porém, as funções de não discriminação, defesa contra o Estado e proteção perante terceiros revelam-se importantes em outro domínio: no estabelecimento de condições materiais para que a igualdade de gênero seja plena.

As referidas funções dos direitos dão ensejo a mecanismos voltados para assegurar a igualdade de gênero - que passam a ser realizadas tanto pela interferência estatal na delimitação das relações de trabalho também por meio de liberdades positivas exigíveis do Estado na figura de prestações materiais.

Além disto, mostra-se necessário estabelecer os parâmetros para a aplicação dos direitos sociais, dentro da lógica dos direitos humanos e das concepções de Estado de Direito que os mesmos realizam, de forma a articular a não discriminação e o pleno reconhecimento social e jurídico das singularidades de gênero e de orientação sexual com os meios materiais para realizá-las.

Neste caso, trata-se também de estabelecer em que condições os direitos sociais podem ser aplicados nas relações de gênero e de orientação sexual de forma a equilibrar o respeito à singularidade e a universalidade a que almejam atingir as prestações a serem garantidas por tais direitos.

Para realizar o intento posto neste trabalho, será articulada uma revisão de literatura sobre direitos sociais, explorando suas conexões com o problema da igualdade e as relações de gênero, com especial atenção aos modelos de política social voltados para a concretização da igualdade de gênero identificados por Nancy Fraser e suas projeções no âmbito do sistema jurídico-constitucional, por meio de análise da normativa constitucional e legal do Estado social no Brasil e suas eventuais projeções na jurisprudência. 


\section{ESTADO DE DIREITO E AS FUNÇÕES DOS DIREITOS HUMANOS SOCIAIS NAS} RELAÇÕES DE GÊNERO

A busca pela compreensão das conexões entre direitos sociais e igualdade de gênero deve necessariamente se ater ao papel mediador que a noção de Estado de Direito exerce quanto à dicotomia universalidade/singularidade (igualdade/diferença), bem como deve buscar analisar como as diferentes funções realizadas pelos direitos humanos e fundamentais atuam neste processo de afirmação da igualdade de gênero.

Não por acaso, Pierre Rosanvallon afirma que "a constituição de uma sociedade de singularidades implica, em primeiro lugar, proporcionar aos indivíduos os instrumentos de sua singularidade, o que necessariamente leva a uma redefinição das políticas sociais" (2012, p. $323-324) .^{2}$

Em outros termos, Antoni Domenèch ${ }^{3}$ (2009) relembra Marx ao afirmar que "quem

\footnotetext{
${ }^{2}$ No trecho original da versão em espanhol: "La constitución de uma sociedade de singularidades implica em primer lugar proporcionar a los indivíduos los instrumentos de su singularidade. Esto conduce a una redefinición de las políticas sociales" (ROSANVALLON, 2012, p. 323-324).

${ }^{3} \mathrm{~A}$ frase de Domenèch consta de entrevista concedida à Myriam Bautista, do Jornal El Tiempo, de Bogotá, e reproduzida no site Carta Maior. Domènech fala sobre experiência de Sin Permiso. Trata-se de uma referência a um trecho do pensamento de Marx exposto em A Crítica ao Programa de Gotha: "Na medida em que o homem se situa de antemão como proprietário diante da natureza, primeira fonte de todos os meios e objetos de trabalho, e a trata como possessão sua, seu trabalho converte-se em fonte de valores de uso, e, portanto, em fonte de riqueza. [...] pois precisamente do fato de que o trabalho está condicionado pela natureza deduz-se que o homem que não dispõe de outra propriedade senão sua força de trabalho, tem que ser, necessariamente, em qualquer estado social e de civilização, escravo de outros homens, daqueles que se tornaram donos das condições materiais de trabalho. E não poderá trabalhar, nem, por conseguinte, viver, a não ser com a sua permissão". O trecho destacado de A Crítica ao Programa de Gotha consta da apresentação da Revista Sin Permiso, periódico do qual Domenèch faz parte (disponível em: $<$ http://www.sinpermiso.info/presentacion/index.php>. Acesso em: 6 fev. 2019) e a versão em português foi obtida a partir do Portal Domínio Público (disponível em: $<$ http://www.dominiopublico.gov.br/download/texto/cv000035.pdf>. Acesso em: 6 fev. 2019). Cabe acrescentar que na entrevista ao Jornal El Tiempo, reproduzida pelo Portal Carta Maior, Domenèch deixa claro, a partir da citação feita, qual seria o programa político de universalização da liberdade republicana: "que ninguém tenha necessidade de ter de pedir permissão a outro para sobreviver, que ninguém seja escravo de outro" (texto disponível em: <https://www.cartamaior.com.br/?/Editoria/Politica/Domenech-fala-sobreexperiencia-de-Sin-Permiso/4/15220. Acesso em: 6 fev. 2019). Ainda que Domenèch se refira às questões sociais referentes ao capital e ao trabalho, ou seja, à dinâmica da justiça distributiva em uma sociedade, não é possível deixar de perceber que alguém que não possa viver de acordo com sua identidade ou que tenha que ser inferioridade por um padrão de status cultural, como as mulheres em sociedades patriarcais e machistas ou os homossexuais sob padrões heteronormativos, também terminam por ter que pedir permissão para viver ao padrão dominante, e se o ideal de um programa de universalização da liberdade republicana é fazer com que ninguém tenha que pedir permissão para viver, então isto deve incluir o respeito à diversidade sexual e à igualdade de homens e mulheres, bem como de quaisquer singularidades que não sejam traduzíveis somente pelo viés distributivo e econômico de classe - assim, a universalização da liberdade republicana, como defendida neste trabalho, só será plena quando a igualdade dela decorrente se traduzir na possibilidade de que as pessoas
} 
não tem meios próprios de vida tem de pedir permissão a outros para viver, e por isso não é livre". Ou seja, "liberdade não é ter que pedir permissão a outro para sobreviver" (DOMENÈCH, 2009).

E quais seriam os meios efetivos para se garantir a igualdade como relação a partir do pleno desenvolvimento das singularidades (no caso, de gênero e de orientação sexual)? Uma vez garantidas condições sociais básicas a todos, por meio do acesso a políticas e serviços sociais universais, isto dissolveria a discriminação fundada em status? Existe vertente da literatura de Direito Constitucional que corrobora esta perspectiva, como demonstra passagem da obra de Daniel Sarmento:

O advento do Estado Social, aliado à progressiva sofisticação nos estudos do Direito Constitucional na Europa, sobretudo no período de reconstrução que se seguiu ao fim da $2^{a}$ Guerra Mundial na Europa, importaram numa mudança significativa na concepção dos direitos fundamentais. Não apenas novos direitos foram positivados, ligados à garantia da igualdade material e das condições básicas de vida para a população, como também a visão referente aos antigos direitos liberais sofreu uma relevante mudança. Tais direitos sujeitar-se-ão doravante a uma nova leitura, que buscará captar outras possibilidades latentes no discurso emancipatório que lhes empresta lastro (SARMENTO, 2004, p. 133).

A crença de Daniel Sarmento no Estado social e no seu papel de afirmação dos direitos fundamentais mostra-se atraente, mas infelizmente acabam recaindo no mito de origem do Estado social, como se o mesmo tivesse transformando radical e substancialmente as relações entre capital e trabalho e representado uma superação das hierarquias fundadas em status. A mistificação do Estado social esconde as continuidades herdadas dos seus antecedentes no desenvolvimento da modernidade política, ao menos no que se refere às relações de gênero.

Se uma das diferenças entre o Direito das sociedades modernas capitalistas e outras formas de Direito historicamente conhecidas é que "o primeiro não impõe a divisão de classes nem a desigualdade social dela decorrente, exprimindo o caráter aberto das classes sociais no capitalismo”, por outro lado não é possível dizer que este Direito da sociedade liberal era "neutro", "na medida em que consagrava normas excludentes que exprimiam a força política das classes dominantes, que conseguiam controlar o Parlamento" (SABADELL, 2008, p. 213214).

tenham os mesmos direitos e o mesmo reconhecimento de acordo com suas singularidades, e que o Estado e a sociedade possam oferecer instrumentos sociais efetivos para que isto se converta não somente em não interferência, mas em liberdade positiva, na plena capacidade material para viver sua singularidade e no suporte prestacional material que isto exige. 
Daí surge a promessa não cumprida do Direito moderno: a suposta neutralidade e a prometida igualdade formal, do ponto de vista do gênero e da sexualidade, não passam de falácias, alternando-se interdições expressas à condição feminina com o uso da linguagem formal e abstrata do Direito moderno para ocultar as diferenças de tratamento, que restariam implícitas.

O Estado Liberal de Direito do século XIX fundava-se em um parlamento que era, como lembrou Gustavo Zagrebelsky (2003), inteiramente dominado por uma única classe social (a burguesia), que normatizava ou positivava seu ideário pela ausência de oposição e contestação legítima diante da ausência dos diferentes no plano da produção legislativa, que terminava por gerar uma legislação coerente e consistente com certos interesses de classe ${ }^{4}$.

Assim, a preservação da família como unidade de produção e instrumento para viabilizar a propriedade privada se tornou tarefa do Estado Liberal, como forma de implantar seus valores e o seu ideal de sociedade, transferindo a tarefa de cuidar das pessoas às famílias, para que o Estado pudesse deter-se na organização do político e na garantia do mercado, sem deixar de vigiar as famílias para que cumprissem sua missão (DONZELOT, 1986; BADINTER, 1985).

A família é, assim, o feixe que organiza todos os institutos fundantes do Direito Privado moderno, tendo no seu cerne a preservação e a ampliação da propriedade privada enquanto junção do trabalho produtivo com a apropriação do trabalho doméstico e reprodutivo a cargo das mulheres, e também uma unidade de direção moral para a internalização e promoção dos valores da sociedade liberal.

O Estado social de Direito modificou parcialmente este arranjo, na medida em que foi antecedido de profundas transformações como a conquista do direito de voto pelas mulheres (como será analisado no capítulo V), o que lhes deu alguma visibilidade em contraponto à exclusão do espaço público no século XIX.

Cabe destacar, no entanto, que nas relações de gênero e no que tange à cisão público/privado e à centralidade do gênero e da sexualidade na sua constituição, o Estado social nada mais é do que a continuação das desigualdades e das diferenças excludentes quanto ao

\footnotetext{
${ }^{4}$ A visão histórica do Estado liberal conforme a exposição de Zagrebelsky (2003) corrobora o pensamento de Marx, que via no Estado liberal-burguês uma mera hegemonia de classe ou, relembrando as palavras do pensador socialista, comitê executivo dos interesses da burguesia - mas a frase transcende o aspecto meramente material ou de hegemonia econômica e implica, no panorama do Estado e da sociedade do século XIX, em uma hegemonia moral, de uma imposição sobre o domínio dos costumes (esfera privada), notadamente sobre a família e a sexualidade (DONZELOT, 1986; BADINTER, 1985).
} 
gênero, articuladas sobre outros aspectos. Como lembra Esping-Andersen (1990, p. 55):

O Estado do bem estar social pode promover serviços e seguridade social, mas é também e tem sempre sido um sistema de estratificação social, sendo Estados que adotam este modelo instituições chave na estruturação das classes e da ordem social, pelo fato de que as características organizacionais do Estado do bem estar social ajudam a determinar a articulação de solidariedade social, divisão de classe e diferenciações de status 5 .

O Estado social se apresentou sob a égide de diversas concepções (conservadoras, liberais e socialistas), mas não foi uma ruptura completa com a sociedade e a estrutura familiar herdadas do liberalismo do século XIX, nem uma superação do capitalismo.

Ao comentar a estratificação promovida pelo Estado do bem-estar social sob a perspectiva de uma política social conservadora, Esping-Andersen (op. cit., p. 58) vai destacar que:

As diferentes visões conservadoras sobre a política social terão como ponto em comum, no caso dos direitos sociais, a aversão à combinação entre o nivelamento social e o antagonismo de classes trazido pelo capitalismo, de modo que, seja em favor de uma hierarquia estrita, do corporativismo ou da prevalência da estrutura familiar tradicional, o tema que unifica os diversos conservadorismos é a ideia de que as relações de status tradicionais devem ser mantidas para o bem da integração social $^{6}$.

Outro exemplo seria a doutrina social da Igreja e sua concepção de política social.

Para a Igreja Católica:

O corporativismo era a resposta natural para suas preocupações em preservar a família tradicional, a busca da Igreja por alternativas viáveis ao capitalismo e ao socialismo, e sua crença na possibilidade de organização harmoniosa entre as classes sociais, ao mesmo tempo em que preservava o princípio católico da "subsidiariedade", pelo qual os mais altos níveis de coletividade social deveriam intervir apenas quando a capacidade de mútua proteção da família se mostrasse impossível (ibid., p. 61). ${ }^{7}$

\footnotetext{
${ }^{5}$ No original em inglês: "the welfare state may provide services and income security, but it is also, and Always has been, a system of social stratification. Welfare states are key institutions in the structuring of class and the social order. The organizational features of the welfare state help determine the articulation of social solidarity, division of class, and status differentiation" (ESPING-ANDERSEN, 1990, p. 55).

${ }^{6}$ No original em inglês: "traditional conservatism, as we have seen, embodies a number of divergente models of the ideal social order. What unites them, as int the case of social rights, is a loathing of the combined social leveling and class antagonisms brought about by capitalism. Be it in favor of strict hierarchy, corporativism, or of familism, the unifying theme is that traditional status relations must be retained for the sake of social integration" (ibid., p. 58).

${ }^{7}$ No original em inglês: "for the catholic church, corporativism was a natural response to its preoccupation with preserving the traditional family, its search for viable alternatives to both socialism and capitalism, and its belief in the possibility of organizing harmonious relations between the social classes. Corporativism inserted easily into Catholicism's "subsidiarity" principle, the idea that higher and larger levels of social collectivity should
} 
Por sua vez, ao tratar dos modelos de estratificação promovidos por uma política social liberal, Esping-Andersen (1990, p. 61-63) vai destacar alguns pontos básicos:

\begin{abstract}
a) abolição de estamentos, guildas, monopólios e absolutismo monárquico centralizador como condições para emancipação individual, liberdade, iguais oportunidades e competição saudáveis; b) a ideia de que o Estado não teria razão legítima para alterar a estratificação produzida pelo mercado; c) o fracasso de um modelo de política social moldado a luz de um individualismo radical e do sistema de alívio da pobreza (neste caso em razão de seu acentuado processo de estigmatização e punição dos pobres), levou a um movimento de reforma liberal, que combinou um mínimo de coletivismo e o individualismo, de sorte a reconhecer que este último deve se alinhar com uma sociedade que se organizava em coletividades.
\end{abstract}

Novamente, ainda que por fundamentos diversos, as políticas sociais, mesmo que construídas sob uma lógica diversa daquelas dos diversos conservadorismos, não negam, pelo contrário, afirmam a lógica das diferenças de status na medida em que a constituição do modelo de intervenção social coexiste e se apoia na família e em outras instituições (como as associações), reproduzindo estigmas e dualismos de classe e, mais importante para os fins deste trabalho, deixando intocada a estruturar familiar, com base no predomínio do masculino.

Diante do legado que as diversas versões do Estado social (welfare) apresentam na questão dos direitos das mulheres, com uma certa continuidade fundada na lógica de status a partir da família, qual o sentido em se refletir sobre a relação entre Estado social e direitos humanos nas relações de gênero?

Explicando mais detalhadamente, a questão que surge consiste em, com base na apontada continuação da dominação de um status masculino e heterossexista no Estado social, identificar em que medida os direitos sociais (trabalhistas e prestacionais) são reflexos da desigualdade sexual e de gênero apontada, reforçando estereótipos e hierarquizações, e se há possibilidade de superação deste legado e suas expressões na normatividade do Estado social.

A resposta surge a partir da conjugação das formulações de Domenèch e Rosanvallon: não só quem perde permissão para viver não é livre, como não há liberdade plena sem os

only intervene when the family's capacity for mutual protection was rendered impossible" (ESPINGANDERSEN, 1990, p. 61). 
meios sociais (materiais) para realizá-la. ${ }^{8}$

Se no Estado pontuado pelo paradigma do constitucionalismo social existem continuidades baseadas em dominação de status é preciso reconhecer também uma mudança paradigmática, herdeira da expansão do sufrágio e da conquista do voto feminino, criando as condições sociais para um cenário jurídico-institucional no qual a lei

já não é expressão pacífica de uma sociedade inteiramente coerente, se não a manifestação de um instrumento de competição e enfrentamento social, tornandose apenas a continuação de um conflito, deixando de ser um ato impessoal, geral e abstrato e convertendo-se em ato personalizado (no sentido de que provém de grupos identificáveis de pessoas e está dirigido a outros grupos igualmente identificáveis) que persegue interesses particulares (ZAGREBELSKY, 2003, p. 38). ${ }^{9}$

Isto mostra que o caminho para compreender a redefinição do papel dos direitos sociais nas relações de gênero no âmbito do Estado Constitucional de Direito contemporâneo se situa na identificação das transformações paradigmáticas que exploraram o potencial emancipatório dos direitos sociais e as funções que os mesmos exercem para torná-los instrumentos jurídicos de realização do programa político subjacente à ideia de igualdade de gênero.

\footnotetext{
${ }^{8}$ Também os direitos civis, pela articulação das funções de não discriminação, proteção contra terceiros e defesa dos direitos humanos e fundamentais constituem uma forma de viabilizar que a pessoa não tenha que pedir autorização ou permissão do Estado ou de quem quer que seja para viver plenamente sua privacidade de igual modo em relação aos demais cidadãos e cidadãs, sem hierarquizações de gênero e sem discriminação quanto a sua opção sexual. Mas a ideia de garantir a igualdade na vida privada às mulheres e às diversas identidades fundadas na orientação sexual não pode progredir se um emprego for negado em razão do gênero, estado civil ou orientação sexual, se a família diversa da tradicional, uma família com liderança da mulher ou entre pessoas do mesmo sexo, não tiver a proteção da moradia, ou se os/as filhos/as gerados e criados em arranjos familiares diversos não puderem frequentar a escola em razão da condição da mulher ou da opção sexual dos pais, ou se prestações de saúde não estiverem disponíveis para homossexuais e transexuais pela sua orientação sexual, ou se a mulher não puder decidir pelo uso dos meios contraceptivos ou não tiver a plena titularidade de seus direitos reprodutivos, ou se obras ou autores forem banidos das escolas pela sua orientação sexual, enfim, a gama de exemplos citadas traz a importância e o caráter sensível de direitos a prestações sociais para o exercício pleno do livre desenvolvimento da personalidade e a autonomia individual. Não por acaso, o próprio Daniel Sarmento conclui que "no Estado social, o poder se pulveriza na sociedade, distribuindo-se por uma série de instituições intermediárias entre o Estado e o indivíduo. Este poder pode revelar-se ainda mais perigoso para os direitos humanos do que o exercido pelas autoridades públicas, por ser mais opaco, mais fugidio ao controle e não se encontrar democraticamente legitimado" (SARMENTO, 2004, p. 43).

${ }^{9}$ No original: "la ley [...] ya no es la expresión 'pacífica' de uma sociedade política internamente coerente, sino que es manifestación e instrumento de competición y enfrentamento social; no es el final, sino la continuación de um conflito; no es um acto impersonal, general y abstracto [...] es, por el contrario, un acto personalizado (en el sentido de que proviene de grupos identificables de personas y está dirigido a otros grupos igualmente identificábles) que persigue intereses particulares" (ZAGREBELSKY, 2003, p. 38).
} 
3 NÃO DISCRIMINAÇÃO COMO INCLUSÃO: DIREITOS SOCIAIS TRABALHISTAS E RELAÇÕES DE GÊNERO

A categoria dos direitos sociais desdobra-se em duas vertentes: os direitos sociais trabalhistas e os direitos sociais prestacionais. Os primeiros são considerados direitos individuais e coletivos de caráter tutelar nas relações de trabalho, ${ }^{10}$ vinculando os empregadores, sejam eles públicos ou privados. ${ }^{11}$ Estão previstos primordialmente nos art. $7^{\circ}$ a $11^{\mathrm{a}}$ da Constituição brasileira.

Os direitos sociais trabalhistas são direitos públicos subjetivos, exigíveis de imediato em relações jurídicas concretas. Representam a constitucionalização do Direito do Trabalho, e por vezes assumem o papel de direitos de defesa, como explica Ingo Sarlet (2007, p. 203-204):

\begin{abstract}
Especificamente no que concerne aos direitos fundamentais sociais na Constituição de 1988, impõe-se aqui ao menos uma breve referência ao fato de que o conceito de direitos fundamentais sociais no direito constitucional pátrio é um conceito amplo, incluindo tanto posições jurídicas prestacionais (direito à saúde, educação, assistência social etc.), quanto uma gama diversa de direitos de defesa [...]. Assim, verifica-se que boa parte dos direitos dos trabalhadores, positivados nos arts. $7^{\circ}$ a $11^{\circ}$ da nossa Lei Suprema, são, na verdade, concretizações do direito de liberdade e do princípio da igualdade (ou da não discriminação), ou mesmo posições jurídicas dirigidas a uma proteção contra ingerências por parte dos poderes públicos e entidades privadas. É o caso, por exemplo, da limitação da jornada de trabalho (art. $7^{\circ}$, incisos XIII e XIV), do reconhecimento das convenções e acordos coletivos de

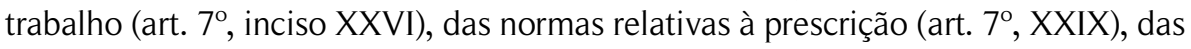
proibições consignadas no art. $7^{\circ}$, incisos XXX e XXXIII, da igualdade de direitos entre o trabalhador com vínculo empregatício e o trabalhador avulso (art. $7^{\circ}$, inciso XXXIV), da liberdade de associação sindical (art. $8^{\circ}$ ), bem como do direito de greve (art. $9^{\circ}$ ), apenas para ficarmos nos exemplos mais evidentes. Em que pese a denominação de direito social [...] o fato é que estes dispositivos - de acordo com o critério da função desempenhada - contém típicos direitos de defesa [...].
\end{abstract}

Mas, se nos direitos civis ou no exercício dos direitos humanos e fundamentais como direitos de defesa, de proteção perante terceiros e de não discriminação haveria o predomínio

\footnotetext{
${ }^{10}$ Conforme trazem Gilmar Ferreira Mendes e Paulo Gustavo Gonet Branco, "a Constituição contempla um leque bastante diferenciado de normas referentes aos chamados direitos sociais do trabalhador. Não são poucas as disposições que regulam as bases da relação contratual e fixam o estatuto básico do vínculo empregatício, conferindo destaque para situações especiais. É notório que a Constituição procurou estabelecer limites ao poder de conformação do legislador e dos próprios contratantes na conformação do contrato de trabalho" (MENDES, 2012, p. 692).

11 "Que trabalhadores disfrutam destes direitos? São os trabalhadores subordinados, aqueles que nutrem vínculo empregatício, que prestam serviços por conta e sob a direção de pessoas físicas ou jurídicas, entidades públicas ou privadas" (BULOS, 2008, p. 626).
} 
de uma lógica de reconhecimento, ao se passar à análise da não discriminação na aplicação dos direitos sociais trabalhistas nas relações de gênero e de orientação sexual surge outra lógica: a da inclusão.

Quando a não discriminação atua em articulação com as funções de direitos de defesa e de proteção contra terceiros no âmbito dos direitos civis isto se dá sob uma ética do reconhecimento, da igual consideração e respeito, e como forma de atribuir a todos os cidadãos e cidadãs, independentemente de seu gênero ou orientação sexual (no caso) os instrumentos jurídico-formais para o pleno exercício de cidadania no espaço público.

Quando falamos dos direitos sociais trabalhistas, a não discriminação tem, além do sentido anteriormente exposto, uma lógica de inclusão, na medida em que cria condições para o igual acesso aos meios materiais de suporte da singularidade/diferença, ou seja, proporciona a efetivação das escolhas de vida relacionadas à personalidade e à identidade a partir de recursos para viabilizá-las.

Neste sentido, o art. $7^{\circ}$, inciso XXX, da Constituição brasileira proíbe diferença de salários, de exercício de funções e de critério de admissão por motivo de sexo, idade, cor ou estado civil.

Cabe iniciar a análise pela questão de gênero, porque aqui há um fator de justiça distributiva aliado à questão do reconhecimento. Por que a igualdade de acesso e permanência no trabalho, bem como a de receber o mesmo salário que os homens, é importante? Relatório do Fundo de Desenvolvimento das Nações Unidas para a Mulher enfrenta esta questão, ao mostrar como a igualdade de direitos entre homens e mulheres no trabalho transpõe a questão da individualidade feminina e se reflete na família:

Há também o reconhecimento de que a igualdade substantiva para mulheres só seja alcançada através de uma série de outras leis e políticas para tornar o ambiente de trabalho mais acessível às mulheres. Central para o sucesso destas políticas é levar em consideração o fato de que em todos os países, as mulheres são primariamente responsáveis pelas tarefas domésticas e de criação dos filhos - trabalho não remunerado que tem impacto sobre sua capacidade de acessar mercado de trabalho em condições de igualdade com os homens. Isso limita suas opções para tirar vantagem das oportunidades formalmente iguais, normalmente relegando as mulheres a tempo parcial, trabalho temporário ou informal, que é menos bem pago e tem menos benefícios ou nenhum (UNITED..., 2011). ${ }^{12}$

\footnotetext{
${ }^{12}$ No original em inglês: "there is also recognition that substantive equality for women will only be achieved through a range of other laws and policies to make the workplace more accessible to women. Central to the success of these policies is taking into account the fact that in all countries, women are primarily responsible for household and child-rearing tasks - unpaid labour which impacts on their ability to access the labour market
} 
Obviamente, há questões mais complexas envolvidas no acesso das mulheres ao direito social ao trabalho, como a própria dinâmica entre mercado de trabalho formal e economia informal, mas a passagem transcrita do Relatório da ONU deixa claro que a igualdade substantiva das mulheres no acesso ao direito social ao trabalho tem um caráter redistributivo forte e implica impacto direto na vida familiar e, particularmente, no desenvolvimento de crianças e adolescentes sob seu cuidado.

Uma das formas de evitar a discriminação e produzir conjuntamente não reconhecimento e não inclusão das mulheres no ambiente do trabalho é a adoção de meios que proíbam a discriminação quanto ao sexo/gênero no acesso ao mercado de trabalho - aqui ocorre uma incidência da igualdade formal, ou igualdade de tratamento, podendo ainda mencionar-se a idéia de imparcialidade como decorrente de uma concepção formal de Estado de Direito e sua aplicação nas relações sociais.

É o que faz, por exemplo, o art. 373-A da CLT, com redação dada pela Lei Federal 9799/1999, ao dispor que ressalvadas as disposições legais destinadas a corrigir as distorções que afetam o acesso da mulher ao mercado de trabalho e certas especificidades estabelecidas nos acordos trabalhistas, é vedado: I - publicar ou fazer publicar anúncio de emprego no qual haja referência ao sexo, à idade, à cor ou à situação familiar, salvo quando a natureza da atividade a ser exercida, pública e notoriamente, assim o exigir; II - recusar emprego, promoção ou motivar a dispensa do trabalho em razão de sexo, idade, cor, situação familiar ou estado de gravidez, salvo quando a natureza da atividade seja notória e publicamente incompatível; III - considerar o sexo, a idade, a cor ou situação familiar como variável determinante para fins de remuneração, formação profissional e oportunidades de ascensão profissional; IV - exigir atestado ou exame, de qualquer natureza, para comprovação de esterilidade ou gravidez, na admissão ou permanência no emprego; V - impedir o acesso ou adotar critérios subjetivos para deferimento de inscrição ou aprovação em concursos, em empresas privadas, em razão de sexo, idade, cor, situação familiar ou estado de gravidez; VI - proceder o empregador ou preposto a revistas íntimas nas empregadas ou funcionárias. ${ }^{13}$

on equal terms to men. This limits their options to take advantage of formally equal opportunities, usually relegating women to part-time, temporary or casual work, which is less well paid and has fewer or no benefits". ${ }^{13}$ A jurisprudência do Tribunal Superior do Trabalho consagrou o entendimento de que a cláusula de vedação da revista íntima no ambiente de trabalho se estende a ambos os sexos, e não apenas às mulheres, conforme a ementa do seguinte acórdão: "DANOS MORAIS. REVISTA ÍNTIMA. CONDUTA OFENSIVA À HONRA E À DIGNIDADE DOS EMPREGADOS. INDENIZAÇÃO. REDUÇÃO PELO TRIBUNAL REGIONAL. FIXAÇÃO NO 
A diretriz assinalada pelo art. $7^{\circ}, \mathrm{XXX}$, da Constituição e especificada na Consolidação

das Leis do Trabalho (art. 373-A, inciso inciso II, com redação dada pela Lei Federal 9799/1999) encontra eco na jurisprudência trabalhista, como demonstram os seguintes precedentes do Tribunal Regional do Trabalho da $5^{\text {a }}$ Região e do Tribunal Superior do Trabalho:

\begin{abstract}
ASSÉDIO MORAL. GRAVIDEZ. DISPENSA DO TRABALHO EM VIRTUDE DA GRAVIDEZ. DISCRIMINAÇÃO. DANO MORAL CARACTERIZADO. O dano moral se caracteriza quando se atinge o patrimônio ideal, protegido pelo que a doutrina denomina de dignidade constitucional, constituído pelos valores inerentes à pessoa humana. $\mathrm{O}$ ato do empregador que manda que empregada grávida permaneça em sua residência, a fim de aguardar o transcurso da gestação sob a justificativa de o seu desempenho não corresponder às expectativas da empresa, pratica nítido assédio moral e, com isso, deve reparar o dano causado (BRASIL, 2007).
\end{abstract}

AGRAVO DE INSTRUMENTO EM RECURSO DE REVISTA INTERPOSTO SOB A ÉGIDE DA LEI N ${ }^{\circ} 13.015 / 2014$ E DO NCPC - NULIDADE DO PEDIDO DE DEMISSÃO - REINTEGRAÇÃO - VERBAS RESCISÓRIAS 1.A questão não foi decidida com base na distribuição do ônus da prova, inocorrendo violação aos arts. 818 da CLT e 373, I, do NCPC. 2. Arestos oriundos de Turmas desta Corte não atendem ao disposto no artigo 896, "a", da CLT. O aresto de fl. 245, oriundo do Eg. TRT não consigna tese divergente a teor da Súmula n 296, I, desta Corte. DANOS MORAIS - CARACTERIZAÇÃO - DISPENSA DISCRIMINATÓRIA - GESTANTE A instância ordinária assinalou que os Reclamados tinham ciência da gravidez da Reclamante e não haver evidências no sentido de que a Autora tenha pedido demissão, como alegado em Recurso de Revista. Concluiu que houve dispensa discriminatória da Recorrida em decorrência da gravidez. A modificação do julgado no ponto esbarra no óbice da Súmula n 126 do TST. INDENIZAÇÃO POR DANOS MORAIS - QUANTUM O Eg. Tribunal Regional, ao fixar o valor da indenização por danos morais, observou os princípios da razoabilidade e da proporcionalidade. Agravo de Instrumento a que se nega provimento. (Tribunal Superior do Trabalho, AIRR - 11751-62.2015.5.01.0015, Relatora Ministra: Maria Cristina Irigoyen Peduzzi, Data de Julgamento: 14/11/2018, $8^{a}$ Turma, Data de Publicação: DEJT 19/11/2018)

Em outro processo, desta vez julgado pelo Tribunal Regional do Trabalho da $3^{\text {a }}$ Região, a mulher foi submetida a exame de gravidez para verificar que no momento de sua demissão não estivesse grávida - a Corte admitiu a possibilidade, mas considerou que a forma

MESMO PATAMAR PARA AMBOS OS SEXOS. PRETENSÃO DE DIFERENCIAÇÃO PELO TEMPO DE SERVIÇO. SÚMULA No 297, I E II, DO TST. VIOLAÇÃO DE PRECEITOS CONSTITUCIONAIS E DIVERGÊNCIA JURISPRUDENCIAL NÃO-CONFIGURADAS. O recurso de revista não se sustenta, no que tange ao inconformismo dos recorrentes quanto à fixação do montante da indenização por danos morais no mesmo patamar para todos os empregados, sem se considerar o tempo de serviço de cada um na empresa. $\mathrm{O}$ Tribunal Regional não apreciou a controvérsia sob tal prisma, mas apenas sob o enfoque da afetação, na mesma intensidade, da conduta da reclamada na dignidade e na honra dos empregados de ambos os sexos [...]" (BRASIL, 2005). 
como foi conduzida foi discriminatória e abusiva:

DANO MORAL. EXIGÊNCIA DE EXAME DE GRAVIDEZ NO ATO DA DISPENSA MEDIANTE PROCEDIMENTO CONSTRANGEDOR. ABUSO DE DIREITO. REPARAÇÃO DEVIDA. O fato de o empregador exigir comprovação de ausência de gravidez no ato da dispensa não configura crime, nos termos da Lei n. 9.029/95, podendo, revelar, de acordo com o procedimento adotado, inclusive, o cuidado de evitar a nulidade da rescisão contratual, atrelada à demanda judicial visando a reintegração da empregada gestante, eis que não é raro o desconhecimento do estado gravídico pela própria obreira. No entanto, a utilização de meios constrangedores, que exponham a trabalhadora à situação vexatória, constitui abuso de direito, sendo devida a reparação civil pela ofensa à dignidade da pessoa humana (BRASIL, 2005).

A Reforma Trabalhista aprovada em 2017 pelo Congresso Nacional (Lei 13467/2017) trouxe a controvérsia acerca da discriminação da mulher no âmbito de trabalho por conta da gravidez ao tratar da questão do trabalho da mulher grávida e lactante em situações de insalubridade, dando nova redação ao art. 394-A da Consolidação das Leis do Trabalho para disciplinar a questão nos seguintes termos:

Art. 394-A. Sem prejuízo de sua remuneração, nesta incluído o valor do adicional de insalubridade, a empregada deverá ser afastada de:

I - atividades consideradas insalubres em grau máximo, enquanto durar a gestação; II - atividades consideradas insalubres em grau médio ou mínimo, quando apresentar atestado de saúde, emitido por médico de confiança da mulher, que recomende o afastamento durante a gestação;

III - atividades consideradas insalubres em qualquer grau, quando apresentar atestado de saúde, emitido por médico de confiança da mulher, que recomende o afastamento durante a lactação.

$\S 1^{\circ}$

$\S 2^{\circ}$ Cabe à empresa pagar o adicional de insalubridade à gestante ou à lactante, efetivando-se a compensação, observado o disposto no art. 248 da Constituição Federal, por ocasião do recolhimento das contribuições incidentes sobre a folha de salários e demais rendimentos pagos ou creditados, a qualquer título, à pessoa física que lhe preste serviço.

$\S 3^{\circ}$ Quando não for possível que a gestante ou a lactante afastada nos termos do caput deste artigo exerça suas atividades em local salubre na empresa, a hipótese será considerada como gravidez de risco e ensejará a percepção de saláriomaternidade, nos termos da Lei $\mathrm{n}^{\circ} 8.213$, de 24 de julho de 1991, durante todo o período de afastamento.

Assim, o art. 394-A da CLT passou a proibir o trabalho da mulher em condições de insalubridade apenas no grau máximo, permitindo o trabalho da trabalhadora gestante em insalubridade em grau médio e mínimo e também da lactante em todos os graus de insalubridade, mas neste caso possibilitando o afastamento do trabalho com garantia da remuneração e emprego mediante atestado de saúde emitido por médico de confiança da 
mulher.

A redação anterior do arr. 394-A, dada pela Lei 13287/2016, estabelecia que empregada gestante ou lactante será afastada, enquanto durar a gestação e a lactação, de quaisquer atividades, operações ou locais insalubres, devendo exercer suas atividades em local salubre.

A medida é um dos pontos controversos da reforma trabalhista, tendo sido defendido pelo Relator da Reforma Trabalhista, o então Deputado Rogério Marinho, nos seguintes termos:

Esse dispositivo tem provocado situações de discriminação ao trabalho da mulher em locais insalubres tanto no momento da contratação quanto na manutenção do emprego. Essa situação é marcante em setores como o hospitalar, em que todas as atividades são consideradas insalubres, o que já tem provocado reflexos nos setores de enfermagem, por exemplo, com o desestímulo à contratação de mulheres. (BRASIL, 2017).

\section{O argumento é desconstruído por Maryland Medeiros da Silva e Paula Isabel Nobrega}

Introine Silva, que analisam estatísticas do setor de saúde e do mercado de trabalho em geral para demonstrar que os dados não sustentam a afirmação do Relator:

O relator do projeto argumenta a não contratação de mulheres no setor da enfermagem, e de médicas em parágrafo posterior, afirmando taxativamente que hoje, não se contratam mais mulheres médicas e enfermeiras que estejam em período fértil. Há de se considerar em primeira análise estatística que a crise econômica, em verdade, é a responsável pela elevação da taxa de desemprego desde o ano de 2014, não guardando qualquer correlação com a Reforma Trabalhista em si. Contudo, os dados verificados é de que não há uma mudança no mercado de trabalho que justifique tal assertiva do Deputado, principalmente nos setores da saúde (medicina, odontologia e veterinária), que estão no contra fluxo da maioria dos outros setores da economia. De acordo com dados do Programa de Disseminação das Estatísticas do Trabalho (PDET), vinculado ao Ministério do Trabalho e Emprego, de julho de 2016 até junho de 2017, período de vigência da lei que vetou o trabalho da gestante em ambientes insalubres, houve crescimento do número de contratações no setor, possuindo um saldo de 40.041 novas vagas, crescimento de 1,99\%, enquanto que no Brasil ocorreu o aumento no número de desempregados em 749.060 (-1,91\%), no mesmo período de avaliação. (BRASIL, 2017e). Nessa primeira análise pode-se inferir que o setor da saúde não sofreu abalo, ao contrário, cresceu e continua crescendo, não tendo fundamento algum o argumento de que está havendo demissões e de que não haverá espaço para as mulheres nesse setor pelo simples motivo de que as gestantes e lactantes serão afastadas dos ambientes insalubres, o que faria surgir, de acordo com o relator, uma postura discriminatória por parte do empresariado. Em uma avaliação especifica do ano de 2016, do período de janeiro a dezembro, com relação aos dados nacionais sem ajustes, no geral houve uma perda de postos de trabalho de 1.371.363, enquanto que os serviços médicos, odontológicos e veterinários tiveram um aumento de 36.420 no mesmo período de avaliação (BRASIL, 2016a). De acordo com dados da Secretaria de Políticas Públicas de Emprego também vinculado ao 
Ministério do Trabalho e Emprego, e com dados fornecidos pelo Observatório Nacional do Mercado de Trabalho, que realizaram um estudo específico sobre a atuação feminina no Mercado de Trabalho, divulgado em 08 de março de 2017, no dia da mulher, que levaram em consideração dados administrativos do Ministério do Trabalho (RAIS e CAGED) e da Pesquisa Nacional por Amostra de Domicílios Contínua do IBGE, há confirmação de que as mulheres de fato são maioria no setor da saúde e serviços sociais, fazendo uma comparação com os anos de 2007 e 2016. Em 2007, haviam 361.713 homens e 1.027.132 mulheres, já em 2016 aumentou para 530.820 homens e 1.707.397 de mulheres, correspondendo a uma variação de $46,8 \%$ a mais de homens e de $66,2 \%$ a mais de mulheres nesses setores da economia (BRASIL, 2017d). Com isso reforça-se a posição de uma não discriminação nesse setor, onde de fato há um domínio pelo sexo feminino, relembrando que desde 2005 com a NR 32 já havia proteção da gestante no setor da saúde com relação a alguns locais insalubres. Que a discriminação da mulher no mercado de trabal ho ocorre, isso é fato, mas não é pelo mero direito de afastamento da gestante dos ambientes insalubres. É algo muito maior, envolve aspectos históricos, culturais e legais também, mas a legislação não é culpada por tal comportamento social, sendo esse o fator menos importante para tamanha regressão (SILVA; SILVA, 2017, pp. 73-74). (grifo nosso).

A controvérsia não se encerrou com a aprovação da reforma trabalhista, pois foi ajuizada a Ação Direta de Inconstitucionalidade número 5938 pela Confederação Nacional dos Trabalhadores Metalúrgicos, alegando a inconstitucionalidade da redação dada pela reforma trabalhista ao art. 394-A da CLT, mais especificamente impugnando os incisos II e III do art. 394-A da CLT.

O Requerente alega em síntese que admitir a possibilidade de que trabalhadoras grávidas ou lactantes desempenhem atividades insalubres nas referidas hipóteses, afrontaria a proteção que a Constituição Federal veementemente atribui à maternidade, à gestação, à saúde, à mulher, ao nascituro, aos recém-nascidos, ao trabalho e ao meio ambiente do trabalho equilibrado, argumento que foi corroborado pela Procuradoria Geral da República em parecer nos seguintes termos:

Assegurar trabalho em ambiente salubre às gestantes e lactantes é medida concretizadora dos direitos fundamentais ao trabalho, à proteção do mercado de trabalho das mulheres, à redução dos riscos laborais e ao meio ambiente de trabalho saudável (Constituição, arts. 6. ${ }^{\circ}, 7^{\circ}-$ XX e XXII e 225). A medida ainda se coaduna com o princípio constitucional dos valores sociais do trabalho e da livre-iniciativa (art. 1. $\left.{ }^{\circ}-\mathrm{IV}\right)$ e com a centralidade do trabalho humano nas ordens econômica e social, proclamada pela Carta Magna (arts. 170 e 193). Não bastasse efetivar direitos e princípios fundamentais de índole trabalhista, a proteção de gestantes e lactantes contra a insalubridade serve especialmente à tutela da saúde, da maternidade e dos direitos mais basilares do nascituro e do lactente. (...) Destarte, o contexto normativo protetivo da saúde, da maternidade e da infância aponta para o afastamento imediato de trabalhadoras gestantes e lactantes de atividades insalubres em qualquer grau. Condicionar tal afastamento à prévia apresentação de atestado médico, como procede a norma impugnada nesta ação direta, é medida desarrazoada que, além de ofender os comandos constitucionais tuitivos, toma o 
trabalho inseguro como bem jurídico, legitimando-o e, em certo ponto, superestimando-o (...)Percebe-se que o art. 394-A-II e III da CLT, com a redação dada pela Lei 13.467/2017, afasta a obrigação do empregador de prover condições adequadas de trabalho à gestante e à lactante, bem como a de manter a incolumidade do meio ambiente de trabalho. Transfere indevidamente para a empregada (parte mais frágil da relação jurídica) e para o médico (profissional alheio ao contrato de trabalho), personagens não sujeitos ao princípio da alteridade (CLT, art. 2. ${ }^{\circ 2}$ ), responsabilidade que lhe cabe por força de sua submissão não só ao complexo normativo protetivo da maternidade e da infância, mas também às normas de saúde, higiene e segurança ocupacional (...) O art. 394-A-II e III da CLT, embora admita o afastamento de gestantes e lactantes de ambientes laborais insalubres, o faz de maneira condicionada e diferida, o que, sob vários aspectos, impede a efetivação dos direitos fundamentais envolvidos, como revelado. A (suposta) proteção - ou melhor, desproteção - que encerra não atende à urgência reclamada pela situação de vulnerabilidade da trabalhadora gestante ou lactante, nem condiz com a relevância dos bens jurídicos em questão (vida, saúde, maternidade, infância e trabalho digno e seguro). Registre-se, por fim, que a norma impugnada contraria também o princípio constitucional da isonomia (arts. 3. ${ }^{\circ}-I I I$ e $5 .^{\circ}-I$ ), na medida em que desconsidera as desigualdades que devem ser sopesadas para que seja possível estabelecer igualdade material ou substancial, inclusive no contexto da empregabilidade (arts. 7. -XX e 170-VIII; Convenção 111 da OIT) (BRASIL, 2018). (grifo nosso).

Em fevereiro de 2019 o processo da ADI 5938 no Supremo Tribunal Federal ainda não havia sido concluído. O relator da ação é o Ministro Alexandre de Moraes ${ }^{14}$.

A mitigação levada a cabo pela reforma trabalhista no que se refere à proteção da mulher contra o trabalho em ambiente insalubre se consubstancia em uma forma de discriminação de gênero que atinge não somente a identidade feminina na sua condição única de gestante/lactante, algo que os homens não partilham, como também se mostra uma discriminação de caráter econômico, submetendo a mulher ao medo do desemprego ou de retaliações de seu empregador caso peça atestado para não trabalhar em condições de insalubridade no grau médio e mínino. Novamente nas palavras de Maryland Medeiros da Silva e Paula Isabel Nobrega Introine Silva:

Outro argumento utilizado para aprovação do projeto da Reforma Trabalhista foi de que seria muito prejudicial a perda salarial da gestante ao se afastar do ambiente insalubre e consequentemente a perda do respectivo adicional. Não haveria nem necessidade de atenção sobre essa justificativa, pois ao utilizá-la como respaldo há uma tentativa clara de compra de dignidade da pessoa humana, utilizando a monetização da saúde, bem da vida que não possui quantificação, pelo contrário, deve ser prioridade quando comparado a outros direitos, principalmente monetários. (SILVA; SILVA, 2017, pp. 74-75).

\footnotetext{
${ }^{14}$ Informações disponíveis em: <http://portal.stf.jus.br/processos/detalhe.asp?incidente=5447065>. Acesso em 7 fev. 2019.
} 
A argumentação dos atores envolvidos ressalta a proteção do nascituro e da criança como cerne da questão, mas a discriminação em razão da gestação e da lactação no ambiente de trabalho é uma questão de gênero e a proteção à maternidade deve ser um respaldo para a proteção à dignidade e à autonomia das mulheres no ambiente de trabalho, não em grau inferior à defesa da criança, mas como um vetor de concretização dos princípios constitucionais que respaldam a opção substantiva pela igualdade de gênero feita pela Constituição brasileira, notadamente a dignidade humana (art. $1^{\circ}$, inciso III), o valor social do trabalho (art. $1^{\circ}$, inciso IV), a não discriminação (art. $3^{\circ}$, inciso IV, e art. $7^{\circ}$, inciso XXXI), a igualdade (art. $5^{\circ}$, caput e inciso I), e a proteção dos direitos das mulheres ao trabalho e à saúde, articulada com a redução dos riscos inerentes ao trabalho, por meio de normas de saúde, higiene e segurança (art. $7^{\circ}$, inciso XXII).

Cabe assinalar que a discriminação contra a mulher no âmbito dos direitos sociais trabalhistas não está relacionada apenas e necessariamente à maternidade ou gravidez, embora a maternidade seja um direito social em si protegido pelo art. $6^{\circ}$ da Constituição. A discriminação da mulher no ambiente de trabalho pode dizer respeito a diversos aspectos da subjetividade feminina.

Daniel Sarmento, por exemplo, traz interessante caso da jurisprudência alemã, mais especificamente do Tribunal Federal do Trabalho alemão. O caso é de 1957, mas mostra-se atual, na medida em que o julgado decidiu pela invalidade de cláusula contratual que previa a extinção do contrato de trabalho de enfermeiras em hospital privado, caso estas viessem a contrair matrimônio (SARMENTO, 2004).

Outra perspectiva de afirmação da não discriminação quanto ao direito social do trabalho no que concerne às mulheres é a adoção de políticas afirmativas de gênero, como faz o art. $7^{\circ}$, inciso XX, da Constituição brasileira, ao prescrever que a lei estabelecerá proteção do mercado de trabalho da mulher, mediante incentivos específicos.

O art. 373-A, parágrafo único, da CLT reforça esta diretriz geral ao buscar estabelecer que as práticas vedadas pelo artigo não obstem a adoção de medidas temporárias que visem ao estabelecimento das políticas de igualdade entre homens e mulheres, em particular as que se destinam a corrigir as distorções que afetam a formação profissional, o acesso ao emprego e as condições gerais de trabalho da mulher (BRASIL, 2012).

Há políticas afirmativas de gênero previstas na própria Constituição brasileira, relativas especificamente à maternidade (que, como dito antes, constitui em si um direito 
social, junto com o trabalho, mas independente deste): licença à gestante, sem prejuízo do emprego e do salário, com a duração de cento e vinte dias (art. 7º inciso XVIII, CRFB/1988) e estabilidade gestante, ou seja, a interdição constitucional da empregada gestante, desde a confirmação da gravidez até cinco meses após o parto. (art. $7^{\circ}$, inciso I, da Constituição c/c art. 10, inciso II, b, do Ato das Disposições Constitucionais Transitórias).

Cabe assinalar que cláusulas de não discriminação que tenham caráter protetivo, articuladas a partir do art. $7^{\circ}, \mathrm{XXX}$, da Constituição brasileira, têm plena justiciabilidade, na medida em que se mostram como uma face do caráter de defesa ou de proteção perante terceiros. Aqui há uma continuidade e uma equivalência com os chamados direitos civis.

Quanto às cláusulas que buscam a não discriminação por políticas afirmativas ou corretivas, há dois modos de analisar a questão. Aquelas concernentes à maternidade, por terem foro constitucional, seriam aplicáveis pela via jurisdicional, seja porque revelam proximidade com a vedação à discriminação, seja porque estão estabelecidas na Constituição em forma de regras, o que viabiliza uma aplicação judicial com menor possibilidade de violar o espaço decisório do legislador democrático infraconstitucional.

Quanto à cláusula constitucional prevista no art. $7^{\circ}$, inciso XX, esta se reveste de caráter de norma programática, ou seja, deve ser viabilizada por políticas públicas de inclusão de gênero a cargo dos poderes políticos, do governo/administração e do legislador democrático.

Não cabe ao judiciário aqui criar, sem legitimação para tanto, os programas de inclusão ou incentivo, ou definir as espécies de benefícios que podem ser estendidos às mulheres para corrigir as distorções e assimetrias no acesso ao mercado de trabalho e seus ganhos.

Tais programas e benefícios devem ser construídos pelo diálogo amplo e a ação política dos agentes públicos constituídos pelos mecanismos representativos democráticos, por instâncias de fiscalização e formulação de políticas públicas pela sociedade civil (caso do Conselho Nacional de Direitos da Mulher, ${ }^{15}$ ou mesmo pela atuação do Conselho Nacional

\footnotetext{
${ }^{15}$ Segundo a página de apresentação do Conselho Nacional de Direitos da Mulher, "O Conselho Nacional dos Direitos da Mulher (CNDM) integra a estrutura do Ministério dos Direitos Humanos (MDH). O CNDM tem como uma de suas importantes atribuições apoiar a Secretaria Nacional de Políticas para Mulheres (SNPM/MDH) em suas articulações com diversas instituições da Administração Pública Federal e com a sociedade civil. O Conselho Nacional dos Direitos da Mulher (CNDM) foi criado em 1985, vinculado ao Ministério da Justiça, para promover políticas que visassem eliminar a discriminação contra a mulher e assegurar sua participação nas atividades políticas, econômicas e culturais do país. De 1985 a 2010, teve suas funções e atribuições bastante alteradas. Em 2003, passou a integrar a estrutura da Secretaria Especial de Políticas para
} 
do Trabalho) ${ }^{16}$ e, em última instância, pelo próprio diálogo com os agentes de mercado e outras instâncias privadas, como categorias profissionais, sindicatos e associações.

\section{CONSTITUIÇÃO, RELAÇÕES DE GÊNERO E OS DIREITOS SOCIAIS PRESTACIONAIS}

Apesar dos avanços apontados quanto aos direitos trabalhistas, é importante perceber que o desafio da igualdade de gênero não se restringe a simplesmente promover o acesso de mulheres ao mercado do trabalho, mas pensar a própria ideia de direitos sociais e das políticas que lhes são atinentes a partir da singularidade de gênero e da diversidade de orientação sexual.

Isto adquire uma importância ainda maior quando se falam nos direitos sociais prestacionais, na medida em que tais direitos exercem a função de mediar vida privada, comunidade política e mundo do trabalho, por meio de prestações que se dirigem para a satisfação dos interesses transindividuais e coletivos, consubstanciados na perspectiva não somente dos trabalhadores e das trabalhadoras, mas da pretensão universal de atender a demandas de todos os cidadãos e cidadãs.

Os direitos sociais prestacionais referem-se aos direitos sociais que demandam uma prestação material por parte do Estado (PESSANHA, 2006), encontrando-se disciplinados principalmente no art. $6^{\circ}$ da Constituição brasileira, assim como nas disposições constitucionais contidas no Capítulo da ordem social (art. 193 e seguintes da Constituição). Os direitos sociais prestacionais exigem, assim, um maior comprometimento do Estado na realização da igualdade social, como evidencia o discurso de Ingo Wolgang Sarlet (2007, p. 232):

Os direitos fundamentais sociais a prestações, diversamente dos direitos de defesa,

Mulheres da Presidência da República, contando em sua composição com representantes da sociedade civil e do governo, o que amplia o processo de controle social sobre as políticas públicas para as mulheres". Disponível em: <http:// https://www.mdh.gov.br/informacao-ao-cidadao/participacao-social/conselho-nacional-dosdireitos-da-mulher-cndm >. Acesso em: 6 fev. 2019. O Conselho Nacional de Direitos da Mulher integra a estrutura do Ministério da Mulher, da Família e dos Direitos Humanos, conforme o art. 44, inciso XIX, da Medida Provisória número 870/2019, ainda pendente de análise pelo Congresso Nacional em fevereiro de 2019 (BRASIl, 2019).

${ }^{16}$ Instituído pelo Decreto Federal número 1617, de 4 de setembro de 199, atualmente regulado pelo Decreto 9028/2017, o Conselho Nacional do Trabalho integrava inicialmente a estrutura organizacional do Ministério do Trabalho (BRASIL, 1995), mas em janeiro de 2019 o referido órgão passou a integrar a estrutura do Ministério da Economia, conforme disposto no art. 32, inciso XXVIII, da Medida Provisória número 870/2019, ainda pendente de análise pelo Congresso Nacional em fevereiro de 2019 (ibid.). 
objetivam assegurar, mediante a compensação das desigualdades sociais, o exercício de uma liberdade e igualdade real e efetiva, que pressupõem um comportamento ativo do Estado, já que a igualdade material não se oferece simplesmente por si mesma, devendo ser devidamente implementada. Ademais, os direitos fundamentais sociais almejam uma igualdade real para todos, atingível apenas por intermédio de uma eliminação das desigualdades [...].

É importante destacar o que está implícito na discussão sobre a forma jurídica de realização dos direitos sociais prestacionais: se tais direitos têm caráter de direitos subjetivos, se são normas programáticas que indicam decisões políticas que vinculam o legislador e a Administração Pública, ou se convivem os aspectos de direitos subjetivos com o de políticas públicas, realizáveis segundo os critérios e possibilidades demarcadas pelos poderes políticos. $^{17}$

Como destaca Érica Pessanha (2006, p. 310), “além dos direitos sociais estarem dispostos de maneira confusa na própria Constituição, propiciando divergências quanto a sua própria definição e fundamentalidade, eles ainda possuem objetos amplos demais, o que dificulta a sua delimitação".

Note-se que quando os direitos sociais prestacionais são concebidos como direitos “prima facie", como faz Carlos Bernal Pulido (2008), surge o problema da sua concretização à luz da possibilidade de restrição e da exigência de proporcionalidade na aplicação de medidas restritivas a estes direitos, como bem observa o referido autor:

Os enunciados dos direitos fundamentais sociais dão lugar a normas e posições
jurídicas prima facie, que admitem restrições legislativas, sempre e quando sejam
proporcionadas. Estas restriç̃̃es podem estar justificadas em razão das limitações
econômicas, e ainda em razão das exigências que se desprendem de outros direitos
fundamentais sociais, democráticos ou de liberdade, ou de outros bens
constitucionais. Desta perspectiva, o princípio da proporcionalidade atua como
critério definidor da vinculação que emana dos enunciados dos direitos sociais. A
análise da proporcionalidade das restrições a estes direitos indica se, nos casos
concretos, as posições em que se concretizam estes direitos valem apenas prima
facie, ou se também valem de maneira definitiva [...]. Segundo esta teoria, as
disposições constitucionais sobre direitos sociais concretizam-se em posições que
impõem ao legislador um determinado dever de legislar - assim como em deveres
de atuação que pesam sobre a administração e sobre o poder judiciário [...]. Nesta
estrutura, o indivíduo tem prima facie um direito, não a um mínimo, senão a todos
os meios materiais necessários para o exercício de suas liberdades, dos direitos
políticos e para o atendimento de suas necessidades básicas. Mas este máximo não

\footnotetext{
${ }^{17}$ Segundo Carlos Bernal Pulido (2008, p. 151), "o problema que dá lugar às diferentes concepções sobre os direitos sociais consiste em estabelecer se a partir das disposições constitucionais sobre os direitos sociais se podem derivar verdadeiros deveres legislativos e administrativos que se concretizem em posições subjetivas exigíveis judicialmente; ou se, pelo contrário, em nenhum caso podem-se determinar estes deveres e então deve concluir que os direitos sociais têm unicamente um sentido político, não vinculante para o legislador e para a administração".
} 
é exigível do Estado de maneira definitiva, se existem outros princípios constitucionais ou limitações materiais que o impeçam, e se isto for demonstrável mediante a aplicação do princípio da proporcionalidade [...]. Pense-se, por exemplo, que seja o caso de demonstrar que a seguridade social não possa dar conta das operações estéticas, pois a subvenção destes procedimentos implicaria a inversão de recursos destinados à atenção de urgências ou comprometeria o oferecimento de medicamentos básicos para combater enfermidades que tenham relação imediata com a sobrevivência (PULIDO, 2008, p. 168-169).

Por sua vez, ao introduzir o conceito de reserva do possível, Lobo Torres (2008, p. 324) explica que este equivale a "reserva democrática", significando, segundo o autor, que “as prestações sociais se legitimam pelo princípio democrático da maioria e pela concessão discricionária do legislador".

Assim, fatores inerentes à própria configuração jurídica dos direitos sociais prestacionais, particularmente sua pretensão universalista e sua definição pela maioria política a serviço de um modelo abstrato de cidadão, trazem complexidade na sua concretização nas relações de gênero e no que concerne à orientação sexual.

Neste sentido, ocorre, na concretização dos direitos sociais prestacionais, uma tensão entre a sua pretensão universal, representada pela maioria democrática consubstanciada nos poderes políticos eleitos (legislativo e executivo), e a reivindicações de singularidade decorrentes de identidades e grupos minoritários, que podem até ter alguma representação política, mas não detém o controle decisório do processo democrático, como as mulheres.

Como conciliar os direitos da maioria no acesso a prestações sociais, ou mesmo na própria definição destas prestações, e como realizar a inclusão das mulheres, para que tenham os meios sociais e materiais de realização plena de suas respectivas trajetórias subjetivas e possam ser e estar no mundo de acordo com suas escolhas existenciais? É possível articular direitos sociais prestacionais, gênero, pluralismo, não discriminação e inclusão? Isto pode ser realizado ou adjudicado pelos juízes?

O caminho para enfrentar estas questões e para compreender as influências das singularidades de gênero na formulação e aplicação de direitos sociais prestacionais, passa pela análise de como as questões de reconhecimento constituídas a partir do ideal do Estado de Direito e das pretensões igualitárias baseadas em direitos humanos podem transformar as estruturas de seguridade social ${ }^{18}$ e realizar a pretensão de pluralidade quanto ao gênero e à

\footnotetext{
${ }^{18}$ A escolha pela seguridade social como fio condutor da análise da incidência da função prestacional dos direitos humanos nas relações de gênero e quanto à orientação sexual não implica ser este o único direito em que isto ocorre, mas sim aquele em que questões privilegiadas sobre a dinâmica entre privacidade e espaço público no constitucionalismo contemporâneo surgem, justamente a partir das identidades femininas e
} 
sexualidade.

Surge então uma questão emblemática sobre relações de gênero e seu impacto na afirmação e justiciabilidade dos direitos prestacionais relacionadas à seguridade social: entender como a questão de gênero perpassa e, de certa forma, molda prestações da seguridade social, ${ }^{19}$ particularmente na efetivação dos direitos à previdência e à assistência social $^{20}$, como suporte ao mundo do trabalho.

\section{A IDENTIDADE DE GÊNERO, SUAS PROJEÇÕES NOS DIREITOS SOCIAIS E NA SUA FUNÇÃO DE ARTICULAÇÃO ENTRE MUNDO DO TRABALHO E SEGURIDADE SOCIAL.}

Pierre Rosanvallon (2012, p. 325) observa que os direitos sociais, "concebidos sob o modelo dos direitos civis e dos direitos políticos, se dirigem ao indivíduo universal e estão, portanto, constituídos por possibilidades automáticas e incondicionadas de acesso a prestações e serviços". ${ }^{21}$

A partir destas observações do autor, é possível reconduzir a questão da formulação e aplicação dos direitos sociais à tensão entre maioria e minoria, entre universalidade e singularidade, na medida em que a desigualdade não conhece uma só face, e a pobreza socioeconômica não é a única forma de violação da igualdade e do Estado de Direito.

A pretensão de universalidade dos direitos sociais prestacionais e sua definição como prestações em prol da coletividade os coloca sob a influência dos desígnios da maioria, sem

\footnotetext{
homossexual/transexual, colocando em evidência o acesso e a própria definição das prestações positivas asseguradas pelo Estado. Certamente, há implicações de gênero e quanto à orientação sexual na afirmação de outros direitos sociais prestacionais, como educação e moradia, e embora sejam mais comumente reconduzíveis às funções de defesa ou de não discriminação dos direitos humanos podem, eventualmente, abarcar também questões prestacionais, como evidencia Martha Nussbaum (1999), ao estabelecer que um direito a ter igual oportunidade de aprender sobre gays e lésbicas, e sobre a homossexualidade em si, o que constitui uma discussão sobre o conteúdo do direito à educação enquanto prestação positiva (não só igual acesso ao ensino e à educação, mas também a possibilidade de um conteúdo plural, o que interfere sobre a realização da prestação em si).

${ }^{19}$ Segundo Fábio Ibrahim Zambitte (2010), a seguridade social pode ser conceituada como a rede protetiva formada pelo Estado e por particulares, com contribuições de todos, incluindo parte dos beneficiários dos direitos, no sentido de estabelecer ações para o sustento das pessoas carentes, trabalhadores em geral e seus dependentes, providenciando a manutenção de um padrão mínimo de vida digna.

${ }^{20}$ Segundo o art. $1^{\circ}$ da Lei 8742/1993, A assistência social, direito do cidadão e dever do Estado, é Política de Seguridade Social não contributiva, que provê os mínimos sociais, realizada através de um conjunto integrado de ações de iniciativa pública e da sociedade, para garantir o atendimento às necessidades básicas.

${ }^{21}$ No trecho original da edição espanhola: "aunque los derechos sociales se conciben según el modelo de los derechos civiles e políticos, se dirigen al individuo universal y están por tanto constituídos por posibilidades automáticas e incondicionadas de acceso a las prestaciones o a los servicios. En este marco es imposible e impensable cualquier individualización" (ROSANVALLON, 2012, p. 323).
} 
levar em conta as singularidades de certos grupos sociais específicos, como bem notou Rosanvallon (2012).

Cumpre notar que pretensões derivadas da reivindicações de autonomia e reconhecimento das mulheres se colocam para além do problema de distribuição de riqueza econômica (dicotomia pobres x ricos), ainda que adquiram contornos específicos no contexto socioeconômico em que se inserem. ${ }^{22}$

É o que traz, por exemplo, Nancy Fraser (1996, p. 222), quando apresenta o combate à pobreza (antipoverty principle) como parte da ideia de igualdade de gênero, declarando que "prevenir a pobreza é crucial em atingir a igualdade de gênero hoje, após o salário da família, considerando as altas taxas de pobreza nas famílias monoparentais lideradas por mulheres e a crescente probabilidade de que mulheres e crianças nos Estados Unidos viverão nestas famílias". 23

Assim, as liberdades sociais positivas que são conhecidas como direitos sociais prestacionais têm em conta, na sua formulação, o indivíduo/cidadão em sua generalidade e de forma abstrata, e, como notou Rosanvallon (op. cit.), priorizam o acesso universal, sem considerar as singularidades e seus desdobramentos, especialmente no que se refere ao gênero.

Por vezes, ainda quando os direitos e políticas sociais prestacionais levam em conta a singularidade, isto não está isento de preconceitos e estereótipos, ainda mais quando o modelo de Estado social (conservador, liberal, social-cristão etc.) se torna uma parte da equação.

Neste sentido e considerando o exposto nos dois últimos parágrafos, as relações de gênero nas sociedades pós-industriais ${ }^{24}$ colocam um desafio à afirmação do direito das

\footnotetext{
${ }^{22}$ Neste sentido, o Relatório da ONU Mulher 2011-2012 (p. 34) evidencia o quão importante o contexto socioeconômico pode ser na realização dos direitos das mulheres, na medida em que "estender a proteção do Estado de Direito para a economia informal e o trabalho vulnerável é de vital importância para a redução da pobreza e da desigualdade, bem como para a garantia dos direitos das mulheres. Isto é particularmente crítico na economia global de hoje, na qual os mercados de trabalho foram desregulamentados e padrões flexibilizados, gerando como resultado que mais e mais empregos sejam informais, com os trabalhadores a perder a proteção social e legal" (Extending the protection of the rule of law to informal and vulnerable work is vitally important to reducing poverty and inequality, as well as to ensuring women's rights. This is particularly critical in today's global economy, as labour markets have been de-regulated and standards relaxed, with the result that more and more jobs have been informalized, with workers losing legal and social protection) (UNITED..., 2011).

${ }^{23}$ No original em inglês: "[...] Preventing poverty is crucial to achieving gender equality now, after the Family wage, given the high rates of poverty in solo-mother families and the vastly increased likehood that U.S. women and children will live in such families" (FRASER, 1996, p. 222).

${ }^{24}$ As mudanças na família decorrentes das transformações vivenciadas nas sociedades pós-industriais foram objeto de análise de Nancy Fraser (op. cit.), reproduzidas no capítulo anterior.
} 
mulheres ao trabalho, tanto como meio de desenvolvimento da personalidade como forma de sustento próprio e da família, o que produz, nas duas vertentes, inclusão.

A melhoria das condições de trabalho e emprego das mulheres por meio da aplicação de padrões de direitos humanos foi defendida pela ONU Mulher, que em seu relatório 2011 2012 defendeu que uma igualdade substantiva para as mulheres, contra a precariedade das relações de trabalho e a dupla jornada (doméstica e não-doméstica) atribuída às mulheres (UNITED..., 2011).

Por um lado, as mudanças socioeconômicas nas sociedades atuais comprovam o avanço das mulheres sobre o mundo do trabalho, com transformações estruturais significativas em relação ao tipo de ocupação.

Gøsta Esping-Andersen analisa dados empíricos de sobre ou sub-representação das mulheres nas ocupações tradicionais e pós-industriais nas relações de trabalho em três países Suécia, Alemanha e Estados Unidos entre 1960 e 1985 e traz a seguinte conclusão:

Com pequenas exceções, há um declínio na segregação ocupacional baseada no gênero. As mulheres foram bem sucedidas em ingressar em trabalhos "masculinos", como a gestão e em profissões técnicas; a sobrerrepresentação delas no gueto dos empregos femininos diminuiu, assim como nos 'empregos precários' (ESPINGANDERSEN, 1990, p. 209). ${ }^{25}$

Esping-Andersen (op. cit., p. 212) nota, ainda, a partir de dados sobre a distribuição de mulheres entre empregos tipicamente masculinos e tipicamente femininos, que "as mulheres estavam se concentrando em empregos femininos (enfermagem, escritório e educação) e também ganhando terreno em ocupações tradicionalmente masculinas".

O trabalho feminino assalariado no contexto de uma economia capitalista não é um fato novo, já estando presente desde a sociedade industrial do século XIX, como notou Eric

\footnotetext{
${ }^{25}$ No original em inglês: "with a few exceptions, there is a decline of women in gender-based occupational segregation. Women have been quite successful in entering privileged 'male-jobs', such as management and the professions; their over-representation in the female-ghetto jobs has lessened, as has their over-representation within the 'junk-jobs'" (ESPING-ANDERSEN, 1990, p. 209). Esping-Andersen nota, contudo, que "o padrão mais intenso verificado é a saída das mulheres dos empregos industriais. Isso pode ser interpretado de duas formas: 1) a desindustrialização tem atingido especialmente as indústrias tradicionalmente "femininas", como as têxteis; 2) tendo menos antiguidade e ligações mais fracas com o emprego, as mulheres podem ter que suportar o peso da decadência industrial. Em todo caso, esta rede resulta no fato de que é mais provável encontrar as mulheres no setor pós-industrial" (The single most dramatic trend is women's departure from industrial-worker jobs. This may be interpreted in two ways: 1) de-industrialization has been especially sweeping within the conventional 'female' industries, such as textiles; 2) having less seniority and weaker job-attachments, women are have been made to bear the brunt of industrial redundancy. Whichever is the case, the net result is that women are much more likely to be found within the post-industrial sector) (ibid., loc. cit.).
} 


\section{RFD}

Hobsbawn (1995).

Neste sentido, o Estado social (welfare) não desconhecia a estratificação de gênero no mundo do trabalho, mas sua resposta em termos de direitos sociais foi limitada, permanecendo presa a desigualdades de gênero substantivas, ainda quando as Constituições do Pós-Segunda Guerra Mundial tenham proclamado solenemente a igualdade entre homens e mulheres, seja em sentido amplo, sejam em sentidos mais restritos (a Constituição brasileira de 1946 limitou-se a estabelecer a igualdade salarial).

Assim, o desafio do Estado Constitucional nas sociedades pós-industriais contemporâneas é enfrentar a questão das desigualdades entre homens e mulheres e na formulação de direitos sociais aplicáveis segundo padrões de igualdade substantiva entre os sexos/gêneros.

A questão é que não há uma única resposta para o desafio de promover igualdade substantiva para mulheres no mundo do trabalho a partir da implementação de padrões de direitos humanos, nem envolve uma única função destes direitos, tampouco é atribuída exclusivamente ao Estado (mas igualmente ao mercado e à sociedade civil).

Do ponto de vista dos modelos de intervenção política para a realização da igualdade de gênero, Nancy Fraser apresenta duas concepções distintas surgidas nas sociedades pósindustriais ${ }^{26}$, com suas diversas nuances: o modelo do(a) mantenedor(a) universal (the universal breadwinner model) e o modelo da paridade do(a) cuidador(a) (the caregiver parity model).

Em comum, ambos os modelos trazem políticas, direitos e intervenções que unem família, relações do trabalho e políticas sociais estatais consubstanciadas em prestações materiais ${ }^{27}$. Existem, porém, algumas diferenças sobre a abordagem da questão de gênero e

\footnotetext{
${ }^{26}$ Segundo Gøsta Esping-Andersen, “a ideia de uma sociedade pós-industrial emergiu na década de 1960, gerada por revoluções contemporâneas na tecnologia, na gestão, no consumo e no emprego. Ela evidencia um novo mundo onde técnicos, profissionais e gestores predomina; onde o trabalho manual à moda antiga desaparece; onde o 'apetite' dos consumidores se volta para os serviços" (the idea of post-industrial society emerged in the 1960s, provoked by contemporary revolutions in technology, management, consumption and employment. It portrays a new world where technicians, professional, and managers predominate; where oldfashioned manual labor disappears; where consumers' appetites are driven towards services) (Esping-Andersen, 1990, p. 191).

${ }^{27}$ Nancy Fraser comenta que o modelo do/da cuidador(a) universal projeta um cenário ambicioso para uma sociedade pós-industrial, o que demanda novos programas e políticas, algumas voltadas para permitir o trabalho feminino, como creche e assistência aos mais velhos, "com o objetivo de libertar as mulheres de responsabilidades não pagas para que eles pudessem ter emprego a tempo inteiro em termos comparáveis aos homens" (aimed as freeing women from unpaid responsabilities so they could take full-time employment on terms comparable to men) (FRASER, 1996, p. 226). Outras políticas exigiriam mudanças culturais, de forma a dissociar a manutenção do espaço doméstico e a masculinidade (breaking the cultural associatiation of
} 
de qual deve ser o papel do Estado na concretização de um direito a assistência social por

meio de políticas públicas.

Nancy Fraser (1996, p. 226-227) apresenta o modelo do(a) mantenedor(a) universal nos seguintes termos:

\begin{abstract}
Em uma visão de sociedade pós-industrial, a idade do salário família iria dar lugar à idade do/da chefe de família universal. Esta é a visão implícita na prática política atual da maioria das feministas norte-americanas e dos liberais. (Foi também assumida em ex-países comunistas!). Pretende alcançar a equidade de gênero, principalmente, através da promoção de emprego das mulheres. O ponto é que as mulheres possam sustentar a si e suas famílias através de seu próprio trabalho assalariado. O papel de ganha-pão é para ser universalizado, em suma, para que as mulheres também, pode ser cidadãs-trabalhadoras [...]. Como este modelo concilia trabalho e cuidado? A maior parte desse trabalho de cuidado seria deslocada da família para o mercado e o Estado, onde seria realizado pelos funcionários remunerados para tal [...]. O/a mantenedor(a) universal, então, é necessariamente um modelo comprometido com uma política de "valor comparável": ela deve corrigir a desvalorização generalizada das competências e dos empregos atualmente codificadas como femininos ou "não-brancos", e deve remunerar esses empregos com nível salarial apto a sustentar a família. ${ }^{28}$
\end{abstract}

breadwinning with masculinity) (FRASER, 1996). Por sua vez, ao se referir ao modelo da paridade de cuidado universal, Fraser (op. cit., p. 231) explica que nele "muitas (se não todas) as mulheres seguirão o padrão atual das mulheres nos Estados Unidos de alternar períodos de trabalho em tempo integral, períodos de trabalhos de cuidados domésticos e períodos que combinem o trabalho em tempo parcial e trabalho de cuidados doméstico igualmente em tempo parcial" (on this model, many - though not all - women Will follow the current U.S. female practice of alternating spells of full-time employment, spells of full-time care-work, and spells that combine part-time care-work with part-time employment). Isso, segundo Nancy Fraser, demandará vários programas de intervenção social, incluindo "um programa de subsídios para compensar o nascimento e a criação dos filhos, tarefas domésticas, e outras formas de trabalho domésticos socialmente necessários", bem como "um programa de reformas nos locais de trabalho, a necessidade óbvia é um programa de suporte à gravidez e de retirada para o âmbito da família, de forma que os/as cuidadores/as possam alternar entre o trabalho de cuidado e emprego sem perder a cobertura da seguridade, e os benefícios associados a ambos devem ser integrados em um único sistema, de modo que os empregos a tempo parcial e apoio aos trabalhos de cuidado devem ser cobertos na mesma base de empregos a tempo inteiro" (a program of caregiver allowances to compensate childbearing, child-raising, housework, and other forms of socially necessary domestic labor [...] also required is a program of workplaces reforms [...] the obvius necessity is a program of mandated pregnancy and family leave so that caregivers can exit and enter employment without losing security or seniority [...]. To assure continuous coverage for people alternating between care-work and employment, benefits attached to both must be integrated in a single system, part-time jobs and supported care-work must be covered on the same basis as full time jobs) (ibid., p. 230-231b).

${ }^{28}$ No original em inglês: In one vision of postindustrial society, the age of the family wage would give way to the age of the universal breadwinner. This is the vision implicit in the current political practice of most U.S. feminists and liberals. (It was also assumed in former communist countries!). It aims to achieve gender equity principally by promoting women's employment. The point is to enable women to support themselves and their families through their own wage-earning. The breadwinner role is to be universalized, in sum, so that women too, can be citizen-workers [...] How would this model organize care-work? The bulk of such work would be shifted from the family to the market and the state, where it would be performed by employees for pays [...] Universal breawinner, then, is necessarily committed to a policy of "comparable worth": it must redress the widespread undervaluation of skills and jobs currently coded as feminine or "nonwhite", and it must remunerate such jobs with breadwinner-level pay (ibid., p. 226-227). 
O/a mantenedor(a) ou o/a provedor(a) universal (também podendo ser chamado de chefe de família universal) parece ser o modelo que orienta a definição constitucional dos direitos sociais trabalhistas na Constituição brasileira de 1988, particularmente ao enunciar a proteção à maternidade e à infância como direitos sociais $\left(\operatorname{art.} 6^{\circ}\right)$ e, no art. $7^{\circ}$, quando garante a licença-gestante (inciso XVIII), a proteção ao mercado de trabalho da mulher (inciso XX), ou a vedação de diferenças salariais fundadas no sexo (inciso XXX).

Não custa também lembrar que o art. 10, II, b do Ato das Disposições Constitucionais estabelece a chamada estabilidade gestante, a garantia à mulher de que não poderá ser demitida da confirmação da gravidez até cinco meses após o parto.

O modelo também se projeta no âmbito da seguridade social e da realização dos direitos prestacionais a ela relacionados, na medida em que um dos princípios da previdência social é a proteção à maternidade, especialmente à gestante (art. 201, inciso II), ao mesmo tempo em que a proteção da maternidade é mencionada como princípio da assistência social (art. 203).

Este é um conjunto de provisões que se aproxima das características descritas para o modelo do/da mantenedor(a) universal, na medida em que garantem condições, formais e materiais, para que a mulher possa, notadamente à luz das particularidades inerentes à maternidade, acessar e permanecer no mercado de trabalho, com iguais direitos sociais garantidos aos trabalhadores homens, para que, assim, possa com eles compartilhar o espaço laboral.

Já o modelo do(a) cuidador(a) universal é apresentado nos seguintes termos por Nancy Fraser (1996, p. 230):

Em uma segunda visão da sociedade pós-industrial, a era do salário-família daria lugar à era da paridade do cuidador. Este é o quadro implícito na prática política da maioria das feministas da Europa Ocidental e socialdemocratas. Destina-se a promover a igualdade de gênero, principalmente através do apoio do trabalho informal de cuidado. O ponto é assegurar que as mulheres, detentoras de importantes responsabilidades domésticas, possam sustentar a si e sua família, quer através de trabalhos de cuidado ou através de trabalhos de cuidado mais emprego a tempo parcial. (Mulheres sem significativas responsabilidades domésticas, presumivelmente, podem se sustentar por um emprego). O objetivo não é fazer a vida das mulheres igual à dos homens, mas sim "fazer a diferença pesar menos". Assim, a criação de filhos e o trabalho doméstico informal são elevados à paridade com o trabalho assalariado formal. O papel do/da cuidador(a) é para ser colocado em pé de igualdade com o papel do/da responsável pelo ganha-pão - para que mulheres e homens possam desfrutar de níveis equivalentes de dignidade e bemestar [...]. Este modelo organiza o trabalho de cuidado muito diferente daquele do 
modelo do/da chefe de família universal. Considerando que no primeiro a abordagem transfere o trabalho de cuidado para o mercado e para o Estado, este mantém a maior parte do trabalho na família e apoiá-lo com fundos públicos. ${ }^{29}$

As referências ao modelo do/da cuidador (a) universal são mais escassas no plano constitucional - pode ser mencionado aqui o art. 201, parágrafos 12 e 13, da Constituição, que preveem um sistema de inclusão previdenciária para aqueles sem renda própria e que se dediquem exclusivamente ao trabalho doméstico no âmbito de sua residência, desde que pertencentes a famílias de baixa-renda, ${ }^{30}$ garantindo-lhes acesso a benefícios de valor igual a um salário-mínimo, alíquotas e carências inferiores às vigentes para os demais segurados do regime geral de previdência social (ambos os dispositivos citados tem redação dada pela Emenda Constitucional 47, de 2005). ${ }^{31}$

Uma referência mais interessante do modelo do/da cuidador(a) universal está na Lei 10836/2004, que institui e define o Programa Bolsa-Família, programa de transferência de

\footnotetext{
${ }^{29}$ No original em inglês: "In a second vision of postindustrial society, the era of the family wage would give way to the era of caregiver parity. This is the picture implicit in the political practice of most Western European feminists and social democrats. It aims to promote gender equality principally by supporting informal care-work. The point is to enable women with significant domestic responsabilities to support themselves and their family either through care-work alone or through care-work plus part-time employment. (Women without significant domestic responsabilities would presumably support themselves throught employment). The aim is not to make women's lives the same as men's but rather to "make difference costless". Thus childbearing, child-rearing, and informal domestic labor are to be elevated to parity with formal paid labor. The carigiver role is to be put on a par with the breadwinner role - so that women and men can enjoy equivalent levels of dignity and well-being [...] This model organizes care-work very differently from universal breadwinner. Whereas that approach shifted care-work to the market and the state, this one keeps the bulk of such work in the household and supports it with public funds" (FRASER, 1996, p. 230-231).

${ }^{30}$ Lena Lavinas (2005, p. 1) não deixa de observar que "se trata, no entanto, de contemplar todas as mulheres, sem exceção, reconhecendo assim e definitivamente a labuta cotidiana do trabalho doméstico como fardo imposto às mulheres em decorrência da divisão social e sexual do trabalho, historicamente responsável pela nada aprazível condição feminina e pelas assimetrias de gênero. De fato, tal proposta visa beneficiar exclusivamente as mulheres mais pobres, capazes de comprovar grau agudo de destituição, aquelas vivendo em famílias cuja renda mensal familiar, ao ser totalizada, fosse inferior a dois salários mínimos". Não é, portanto, uma política social universal, mas sim focalizada, e na questão da renda. Lavinas é crítica deste modelo, afirmando que "a categoria gênero perde centralidade e passa a ser sinônima de 'mulher' ou 'feminino', retirando-se o foco da complexidade das relações sociais para dar destaque a demandas corporativadas porque restritas a grupos ou clientelas específicas" (ibid., p. 6).

${ }^{31} \mathrm{O}$ referido sistema de inclusão especial de trabalhadores/as domésticos/as é regulamentado pelo art. 21, parágrafo $2^{\circ}$, inciso II, alínea b, que define que o benefício previsto no parágrafo 12 do art. 201 da Constituição será destinado a "segurado facultativo sem renda própria que se dedique exclusivamente ao trabalho doméstico no âmbito de sua residência, desde que pertencente a família de baixa renda". A alíquota definida é de $5 \%$. O conceito de baixa renda é dado pelo parágrafo $4^{\circ}$ do art. 21 da Lei 8212/1991, considerando como tal "a família inscrita no Cadastro Único para Programas Sociais do Governo Federal - CadÚnico cuja renda mensal seja de até 2 (dois) salários mínimos". Todos os dispositivos têm redação dada pela Lei Federal número 12470/2011). Texto da Lei 8212/1991, disponível em: <http://www.planalto.gov.br/ccivil_03/leis/L8212cons.htm>. Acesso em: 19 fev. 2013. Note-se que os dispositivos mencionados não definem prazos de carência diferenciados, como exige o art. 201, parágrafo 13, da Constituição, mas apenas uma alíquota diferenciada/privilegiada em relação às demais vigentes, de modo que, quanto à carência, há omissão inconstitucional do legislador.
} 


\section{RFD}

renda do governo federal voltado a famílias de baixa renda. $\mathrm{O}$ art. $2^{\circ}$, parágrafo 14 , diz que o pagamento dos benefícios previstos no Programa será feito preferencialmente à mulher.

O art. 23-A do Decreto Federal número 5209, de 2004 (regulamento do bolsa-família), reitera esta diretriz, ao estabelecer que o titular do benefício do Programa Bolsa Família será preferencialmente a mulher, devendo, quando possível, ser ela previamente indicada como responsável pela unidade familiar no ato do cadastramento (BRASIL, 2003, 2004).

O confronto entre os modelos apresentados, longe de ser uma discussão teórica ou de alcance restrito às famílias com filhos ou idosos sob seu cuidado, coloca o gênero no cerne da formatação de um sistema de seguridade social como suporte para as relações de trabalho em uma economia capitalista pós-industrial - o que põe em evidência os desdobramentos da seguridade (previdência pública, saúde e assistência social) como as bases para uma integração fundada na complementaridade entre Estado, mercado e sociedade civil.

Como mostra Tânia Steren dos Santos (2008, p. 100), "na realidade social contemporânea, a igualdade de condições de vida e trabalho entre homens e mulheres passa necessariamente pela questão da articulação da esfera profissional com a doméstica e por oportunidades mais igualitárias entre os sexos na esfera pública e no lar".

Isto coloca à prova a política de reconhecimento nas relações de gênero baseada no ideal de Estado de Direito formal e na sua formulação substantiva democrática e igualitária: a reciprocidade fundada na confiança da vinculação do Estado ao Direito posto e ao igual tratamento de seus cidadãos e cidadãs não se esgotam no igual respeito - a inclusão (entendida como conjunto dos meios, direitos e políticas, para gerar a igualdade e garantir a dignidade social do outro) é parte essencial do reconhecimento.

Isto transforma a função prestacional dos direitos humanos e sua aplicação nas relações de gênero sob a égide do Estado social em um desdobramento necessário da não discriminação e do reconhecimento, de modo que as mudanças no espaço público provenientes das transformações da privacidade familiar exigem que os direitos e prestações sociais sejam pensados à luz destas mudanças, integrando o masculino e o feminino como singularidades complementares.

O problema, então, passa a ser como fazer para que os programas de assistência pública, a legislação para regular o mundo do trabalho e os programas de previdência do Estado social sejam fundados nestes novos parâmetros de reconhecimento, e não centrados em um único modelo de família e em uma única interação entre masculino e feminino dentro 
e fora do espaço doméstico.

Em outras palavras, como fugir da dicotomia trabalho produtivo vs. trabalho reprodutivo, moldada na divisão entre homem provedor e mulher cuidadora, particularmente na formulação e aplicação dos direitos sociais prestacionais subjacentes ao mundo do trabalho e à efetivação da cidadania?

Os dois modelos descritos por Nancy Fraser (1996) de política social e de efetivação das condições sociais para viabilizar o acesso das mulheres ao trabalho e ao emprego são propostas legítimas de intervenção social do Estado, mas ambos possuem limitações ao tentar realizar a igualdade de gênero como modelo de Estado de Direito substantivo.

Ao avaliar em que medida cada um destes modelos promove o antiandrocentrismo ${ }^{32}$, Fraser avalia que o modelo do(a) mantenedor(a) universal falha em promover igualdade de gênero, pois valoriza o espaço tradicional do homem - o emprego - tentando apenas enquadrar as mulheres nele, instrumentalizando, para tanto, o trabalho de cuidado doméstico, não reconhecendo o valor social deste (ibid.). ${ }^{33}$

O modelo do(a) cuidador(a) universal também apresenta limitações quanto ao enfrentamento do androcentrismo. Segundo Nancy Fraser (op. cit., p. 233),

embora seja melhor do que o modelo do/da mantenedor(a) universal no combate

\footnotetext{
${ }^{32}$ Nancy Fraser (1996) busca demarcar o conteúdo da igualdade de gênero, desdobrando-o em sete princípios: antipobreza, antiexploração, igualdade de renda, igualdade de tempo para o lazer, igualdade de respeito, antimarginalização e o antiandrocentismo (antipoverty, antiexploitation, income equality, leisure-time equality, equality of respect, antimarginalization, antiandrocentism). O que está em jogo, para Fraser, é um conjunto de princípios que, articulados, promovem a igualdade de gênero, no contexto do Estado do Bem Estar Social (welfare state), e que funcionam em cadeia sucessiva: os dois primeiros princípios têm um conteúdo socioeconômico prevalente, não dizendo necessariamente respeito à desigualdade de gênero; Fraser, então, recorre aos chamados princípios de igualdade, os cinco seguintes, mas mesmo entre eles haveria a necessidade de realização conjunta, pois isoladamente cada um não poderia promover, por si só, igualdade de gênero mesmo avançando em relação às questões de combate à pobreza e à exploração, a garantia de igualdade de renda e de tempo livre não afastaria por completo a discriminação de gênero, ao passo que a igualdade de respeito e a antimarginalização só se realizariam plenamente se a elas for acoplado o antiandrocentrismo, pois o predomínio dos padrões de vida masculinos sobre a dimensão do feminino seria a chave para compreender a desigualdade de gênero, pois exigiria que as mulheres se tornassem como os homens ou se adequassem a estes padrões masculinos, sem valorizar a singularidade feminina. A luta contra o androcentrismo mudaria não somente a vida das mulheres, mas dos homens também. Embora todos os princípios sejam necessários para construir a ideia complexa de igualdade de gênero, faz-se uma opção aqui de analisar a realização dos direitos sociais ao trabalho e à assistência social no contexto da seguridade social a partir do antiandrocentrismo, pois coloca em evidência questões de reconhecimento que se convertem em questões de inclusão. Para uma avaliação dos sete princípios da igualdade de gênero segundo Nancy Fraser e sua aplicação aos modelos de realização da igualdade de gênero no Estado social das sociedades pós-industriais, recomenda-se a consulta a seu artigo Gender Equity and the Welfare State: A Postindustrial Thought Experiment.

${ }^{33}$ No original em inglês: "[...] it valorizes men's traditional sphere - employment - and simply tries to help women fit in. Traditionally female care-work, in contrast, is treated instrumentally [...] it os not itself accorded social value" (ibid., p. 229).
} 
do androcentrismo, na medida em que trata o trabalho de cuidado doméstico como valioso em si, e não como obstáculo ao emprego, enfrentando a noção de que somente as atividades masculinas são totalmente humanas, acomodando padrões de vida femininos [...] não valoriza o trabalho doméstico o suficiente para exigir que os homens também o façam. ${ }^{34}$

Nancy Fraser (1996, p. 234) argumenta que

os dois modelos representam uma visão utópica de um Estado do Bem Estar Social pós-industrial, considerando que nenhum deles deve ser realizado tão cedo, na medida em que se baseiam em pré-condições majoritariamente ausentes atualmente, exigindo grandes reestruturações político-econômicas, embora, na visão da autora, não sejam utópicos de forma suficiente na realização da igualdade de gênero. ${ }^{35}$

Como ideais regulatórios sobre a questão do gênero no mundo do trabalho e seus desdobramentos sobre os direitos sociais prestacionais no panorama das sociedades pósindustriais, as projeções destes modelos no Direito brasileiro são sutis, mas produzem resultados, tais como a decisões judiciais trabalhistas mencionadas anteriormente, que ilustram a funcionalidade dos mecanismos de proteção à maternidade no âmbito das relações de trabalho por conta dos direitos sociais e mecanismos constitucionalmente consagrados de defesa da singularidade feminina de ser mãe.

No que tange às políticas de concretização do direito à assistência social, há um recorte de gênero nas ações de transferência de renda, criando as condições para fortalecer a identidade feminina, conforme registra reportagem da Revista Marie Claire, de março de 2012, na qual pesquisa da antropóloga Walquíria Domingues Leão Rêgo sobre o impacto do programa bolsa família nas relações de gênero em regiões de extrema pobreza é abordada:

Uma revolução está em curso. Silencioso e lento - 52 anos depois da criação da pílula anticoncepcional - o feminismo começa a tomar forma nos rincões mais pobres e, possivelmente, mais machistas do Brasil. O interior do Piauí, o litoral de Alagoas, o Vale do Jequitinhonha, em Minas, o interior do Maranhão e a periferia de São Luís são o cenário desse movimento. Quem o descreve é a antropóloga

\footnotetext{
${ }^{34}$ No original em inglês: "[...] yet cargiver parity is better than universal breadwinner at combating androcentrism. It treats caregiver as intrinsically valuable, not as a mere obstacle to employment, thus challenging the view that only men's traditional activities are fully human. It also accommodates 'feminine' life patterns [...]. But [...] it does not value caregiving enough to demand that men do it, too [...]" (FRASER, 1996, p. 233).

${ }^{35}$ No original em ingles: "both universal breadwinner and caregiver parity are highly utopian visions of a postindustrial welfare state. Either one of them would represent a major improvement over current U.S. arrengements. Yet neither is likely to be realized soon. Both models assume background preconditions that are strinkingly absente today. Both presuppose major political-economic restructuring [...] if both models are utopian in this sense, neither is utopian enough [...]" (ibid., p. 234).
} 
Walquiria Domingues Leão Rêgo, da Universidade Estadual de Campinas (Unicamp) [...]. As áreas visitadas por Walquiria são aquelas onde, às vezes, as famílias não conseguem obter renda alguma ao longo de um mês inteiro. Acabam por viver de trocas. O mercado de trabalho é exíguo para os homens. O que esperar, então, de vagas para mulheres. Há pouco acesso à educação e saúde. Filhos costumam ser muitos. A estrutura é patriarcal e religiosa. A mulher está sempre sob o jugo do pai, do marido ou do padre/pastor [...] Walquiria queria saber se, para essas pessoas, o Bolsa Família havia se transformado numa bengala assistencialista ou resgatara algum senso de cidadania [...]. "Há mais liberdade no dinheiro", resume Edineide, uma das entrevistadas de Walquiria, residente em Pasmadinho, no Vale do Jequitinhonha. As mulheres são mais de $90 \%$ das titulares do Bolsa Família: são elas que, mês a mês, sacam o dinheiro na boca do caixa. Edineide traduz o significado dessa opção do governo por dar o cartão do benefício para a mulher: "Quando o marido vai comprar, ele compra o que ele quer. E se eu for, eu compro o que eu quero." Elas passaram a comprar Danone para as crianças. E, a ter direito à vaidade. Walquiria testemunhou mulheres comprarem batons para si mesmas pela primeira vez na vida. Finalmente, tiveram o poder de escolha. E isso muda muitas coisas. "Boa parte delas tem uma renda fixa pela primeira vez. E várias passaram a ter mais dinheiro do que os maridos", diz Walquiria. Mais do que escolher entre comprar macarrão ou arroz, o Bolsa-Família permitiu a elas decidir também se querem ou não continuar com o marido. Nessas regiões, ainda é raro que a mulher tome a iniciativa da separação. Mas isso começa a acontecer, como relata Walquiria: "Na primeira entrevista feita, em abril de 2006, com Quitéria Ferreira da Silva, de 34 anos, casada e mãe de três filhos pequenos,em Inhapi, perguntei-lhe sobre as questões dos maus tratos. Ela chorou e me disse que não queria falar sobre isso. No ano seguinte, quando retornei, encontrei-a separada do marido, ostentando uma aparência muito mais tranqüila."A despeito do assédio dos maridos, nenhuma das mulheres ouvidas por Walquiria admitiu ceder aos apelos deles e dar na mão dos homens o dinheiro do Bolsa. "Este dinheiro é meu, o Lula deu pra mim (sic) cuidar dos meus filhos e netos. Pra quê eu vou dar pra marido agora? Dou não!", disse Maria das Mercês Pinheiro Dias, de 60 anos, mãe de seis filhos, moradora de São Luís, em entrevista em 2009. Walquiria relata ainda que aumentou o número de mulheres que procuram por métodos anticoncepcionais. Elas passaram a se sentir mais à vontade para tomar decisões sobre o próprio corpo, sobre a sua vida. É claro que as mudanças ainda são tênues. Ninguém que visite essas áreas vai encontrar mulheres queimando sutiãs e citando Betty Friedan [...] (SANCHES, 2012).

\section{Os efeitos de programas de assistência social como o Bolsa Família nas relações de gênero foram notados igualmente Letícia Bartholo, que identificou traços de empoderamento feminino no programa em linhas semelhantes àquelas descritas por por Walquíria Rêgo:}

O Brasil dispõe de resultados de pesquisas de cobertura nacional sobre o bem-estar das mulheres do PBF basicamente nas duas rodadas da pesquisa de Avaliação de Impacto sobre o Programa (AIBF), efetuadas em 2005 e 2009, e em pesquisa sobre repercussões do Bolsa Família na segurança alimentar e nutricional das famílias, realizada em 2007 pelo Instituto Brasileiro de Análises Sociais e Econômicas (IBASE). Talvez pelo viés maternalista do PBF, ou mesmo pela clareza de que só pode ter efeitos limitados nas relações de gênero, as pesquisas circunscrevem o exame do bem-estar feminino a questões sobre saúde reprodutiva e autonomia decisória no domićlio. A AIBF avaliou o impacto do PBF sobre o bem-estar feminino a partir de dois conjuntos de indicadores: número de consultas pré-natais e tomada de decisões no domicílio. Entre 2005 e 2009, o número médio de consultas de pré-natal frequentadas pelas beneficiárias passou de 3,5 para 4,4. Entre as não beneficiárias do grupo de comparação, os números foram de 2,9 e 4,3 para 
os anos da primeira e segunda rodadas, respectivamente. O Bolsa Família contribuiu para que as gestantes beneficiárias em 2009 tivessem 1,6 consultas de pré-natal a mais, comparativamente às gestantes não beneficiárias, mas esse impacto precisa ser interpretado com cautela, pelo limitado tamanho da amostra de gestantes no período da pesquisa. Também foi positiva a queda na proporção entre as beneficiárias que não tiveram nenhuma consulta pré-natal durante a gestação, que passou de, aproximadamente, 17,7 por cento para 5,7 por cento. Contudo, esse impacto não é estatisticamente significante (DE BRAUW, 2010). As duas rodadas da AIBF também questionaram as respondentes sobre quem tomava as decisões no domicílio: exclusivamente as mulheres; as mulheres e seus parceiros; ou exclusivamente os parceiros. As dimensões abordadas foram: compra de comida; vestimentas para si, para o parceiro e para as crianças; gastos com saúde das crianças; se a criança deve deixar de ir à escola; aquisição de bens de consumo duráveis para a casa; se a mulher deve trabalhar ou não; se o cônjuge deve trabalhar ou não; e sobre a decisão de usar métodos anticonceptivos. Em ambos os anos, a maior parte das mulheres afirmou tomar as decisões conjuntamente, e as que estavam sem a presença do cônjuge, no momento da pesquisa, tenderam a dar mais respostas de exclusividade nas decisões. Em 2009, nota-se um impacto de, aproximadamente, 10 pontos percentuais do PBF na decisão individual das mulheres sobre o uso de métodos contraceptivos. O exame do tema conforme o local de moradia demonstra que os impactos positivos do Bolsa Família, na tomada de decisão exclusiva das mulheres, são inexpressivos no meio rural, estando concentrados nas áreas urbanas. Nestas, o efeito positivo do PBF sobre as decisões exclusivas femininas aumenta para 16 por cento a 18 por cento em relação ao uso de contraceptivos, 8 por cento a 14 por cento sobre a compra de bens duráveis, 13 por cento a 15 por cento em relação aos gastos com a saúde das crianças e 12 por cento a 15 por cento sobre a decisão do comparecimento da criança à escola (DE BRAUW et al., 2014). O aumento das decisões exclusivas sobre temas domésticos entre as mulheres da área urbana implica maior autonomia decisória, mas o resultado não pode ser considerado positivo em termos de equidade de gênero afinal, pode representar um afastamento maior dos homens da esfera doméstica e, portanto, mais sobrecarga para as mulheres. Já a decisão sobre o uso de métodos contraceptivos significa claramente a ampliação dos direitos reprodutivos femininos: autonomia decisória sobre o próprio corpo e a decisão de ter filhos. Esse resultado pode estar vinculado à maior frequência das mulheres ao sistema de saúde ou ao próprio valor monetário do benefício, podendo sugerir que o PBF tem a potencialidade de atuar como instrumento de concretização do exercício de direitos reprodutivos nessas áreas. (BARTHOLO, 2016, pp. 2-3).

Não se pode negligenciar que o desenho legal-institucional do programa o aproxima do modelo de cuidador(a) universal, valorizando o papel da mulher na gestão do bem-estar da família, particularmente no cuidado com os filhos, preconizando uma política de assistência social que valorize o espaço doméstico e a função da mulher neste espaço, dandolhe protagonismo, que cria condições para valorizar sua individualidade, ainda que sob diversas contingências, como mostra a reportagem da Revista Marie Claire.

Do ponto de vista do enfrentamento ao androcentrismo, porém, é emblemático que a política social remeta à família para designar um de seus programas mais importantes e que atribua às mulheres um empoderamento que, por sua vez, é também um dever de cuidado de si e de outros, particularmente das crianças, como se a condição feminina implicasse em um 
imperativo de solidariedade, notadamente no que tange à família. Como mostram Luciane

Lucas e Tânia Hoff (2008, p. 143):

Quanto à interface entre gênero e pobreza, pode-se dizer que o Programa Bolsa Família suscita uma série de considerações, embora não tenha sido desenhado com a finalidade de ser uma política de gênero. $\mathrm{O}$ fato de estabelecer a mulher como titular do cartão de recebimento do benefício tem certamente desdobramentos positivos, mas a escolha se deve, antes, ao seu papel na manutenção da família e no cuidado com os filhos. Ainda assim, é inegável que o desenho do programa, ao colocar a mulher no centro da família, altera a lógica da discursificação dominante de gênero. Contudo, o desenho do programa também apresenta pontos críticos em relação às questões de gênero, alguns dos quais já mencionamos anteriormente. Assim, a unidade familiar [...] só poderá receber o benefício se houver, na composição familiar, mulheres grávidas, em amamentação ou filhos de 0 a 15 anos. Isso significa, primeiramente, que mulheres pobres sem filhos não têm acesso ao benefício, a não ser que estejam na faixa da extrema pobreza [...], o que reforça não só um sentido de família que pressuponha filhos, como também uma imagem de mulher associada à sua função biológica.

Neste sentido, pesquisa do Observatório de Igualdade de Gênero da Comissão Econômica para América Latina e Caribe (CEPAL) mostra que os programas de transferência de renda podem perpetuar o vínculo da mulher no âmbito do trabalho doméstico de cuidado. O estudo realizado pela CEPAL destacou a relação entre os programas de transferência de renda (PTC), como o bolsa-família, e o "maternalismo social”, indicando que:

São programas "feminizados", no sentido de que a maioria dos que recebem o benefício monetário são mulheres. No entanto, esta percepção não obedece ao reconhecimento de um direito próprio, mas derivado. De fato, os titulares do direito para acessar o benefício são, em geral, as crianças e adolescentes. Em consequência, as mulheres atuam como beneficiárias operacionais do programa (...). Exigem condicionalidades, vinculadas com a assistência escolar e o controle de saúde das crianças, adolescentes e, em alguns casos, das mulheres grávidas. Na maioria dos casos se fazem valer de maneira punitiva (se não forem cumpridas, perde-se total ou parcialmente o benefício) (...) As condicionalidades de assistência escolar e controle da saúde das crianças e adolescentes como característica distintiva dos PTC constituem um meio através do qual opera o que podemos chamar de "maternalismo social". Este termo alude ao fato de que a política social considera as mães como corresponsáveis na consecução de certos objetivos sociais (como a superação da pobreza). As mães se transformam assim num instrumento da política social, o que se soma à sua responsabilidade histórica de garantir a reprodução social cotidiana das pessoas (...)obrigação para as receptoras do benefício monetário dos PTC de demonstrar a frequência escolar e o controle de saúde de seus filhos passou de se basear numa ideia de condicionalidade a uma noção de corresponsabilidade. Isto implica que o cumprimento dos requisitos deixou de ser uma condição para receber o benefício e se transformou num mecanismo pelo qual as mães são agora responsáveis por garantir o correto investimento em capital humano de seus filhos, o que resultará com o tempo na superação de sua condição de pobreza. Isto ocorre sobretudo nos programas em que o não cumprimento dos requisitos é administrado de maneira estritamente punitiva, ou seja, onde supõe a perda parcial ou total do benefício (...). Ao tornar as mães explicitamente 
responsáveis por velar por estas dimensões de cuidado (educação e saúde), os PTC reforçam o papel cuidador das mulheres, que é uma das causas da desigualdade econômica de gênero. Portanto, a capacidade que os PTC podem ter para transformar a vida das mulheres pobres com a transferência de renda monetária (um passo adiante) é neutralizada com folga ao fazê-lo consolidando seu papel cuidador, o que tem mais de uma implicação negativa (dois passos atrás). (ONUBR, pp. 50 e 61-62, 2013).

Assim, a realização da igualdade de gênero no sistema de proteção social, por meio de um direito à segurança social (previdência e assistência), é algo complexo e, ainda que seja eficaz na luta contra a pobreza ou contra a marginalização que atingem as mulheres, podem revelar diversas nuances de androcentrismo e prolongar a reprodução da mulher como mãe e como trabalhadora doméstica de cuidado, e não como alguém que merece ser titular da assistência e da proteção do Estado por direito próprio decorrente de sua condição cidadã.

\section{CONCLUSÕES}

A realização da igualdade de gênero e da orientação sexual como imperativo de uma concepção formal e substantiva de Estado de Direito não se esgota no reconhecimento, entendido como atribuição de iguais direitos e consideração, mas este é o ponto de partida para a promoção da igualdade de gênero como forma de inclusão da diferença/singularidade no âmbito do Estado Constitucional.

Neste sentido, os direitos sociais exercem um papel importante na promoção não apenas de reconhecimento, mas da inclusão como efetivação do mesmo, e como base mesmo para a construção da participação política.

Se o Estado social e os direitos, trabalhistas e prestacionais, dele surgidos tiveram como base um modelo universal de homem/cidadão, e foram, no nascedouro, a continuidade do formato da família tradicional, da dominação de gênero e da discriminação sexual como bases para as políticas sociais do Estado, isto se redefiniu a partir da ascensão das singularidades como a identidade feminina, de forma a reivindicar uma nova concepção de Estado de Direito, baseada na igualdade de gênero como formas de redefinir o acesso e a própria noção das prestações objeto dos direitos sociais.

Os direitos sociais aparecem então não para atestar a insuficiência do reconhecimento, mas para agregar uma nova fase do mesmo, e a demanda de igualdade como relação social, na qual as singularidades dialogam com a universalidade, é potencializada pelos direitos 
sociais, na medida em que eles não realizam apenas inclusão, mas diferentes formas de inclusão nas relações de gênero.

Primeiro, os direitos sociais trabalhistas, ainda como direitos de defesa e no marco da função de não discriminação, servem como forma de garantir as bases materiais do reconhecimento, para que não seja preciso pedir permissão para ser reconhecido e para viver cada identidade/singularidade - é o que está presente na defesa dos direitos sociais trabalhistas das mulheres, notadamente no marco do modelo constitucional brasileiro, que garante vários destes direitos.

A principal contribuição da identidade feminina à formulação e aplicação de direitos sociais no contexto do constitucionalismo contemporâneo e à luz das dimensões do Estado de Direito diz respeito à redefinição do acesso e da própria configuração dos direitos sociais prestacionais, contribuindo para mediar a universalidade posta pela vontade da maioria, e as particularidades decorrentes das identidades singulares das mulheres.

Ainda assim, a aplicação dos direitos sociais nas relações envolvendo questões de gênero não se apresenta isenta de risco, notadamente a possibilidade de retorno a um modelo paternalista, com a perpetuação de estereótipos nas relações de gênero que impeçam a concretização de pretensões igualitárias.

Por sua vez, os direitos sociais são liberdades positivas concebidas como universais no seu acesso e no seu alcance, ou seja, buscam a realização do bem-estar geral de trabalhadores/as e cidadãos/cidadãs, buscando produzir o bem de todos/as.

Tais direitos devem ser realizados em atenção às particularidade/singularidades postas por identidades de grupo, mas são, antes de tudo, um esforço da maioria por intermédio do Estado, ou de outros segmentos sociais que não somente as minorias, como os empregadores (públicos e privados), e, no caso do sistema de segurança social, outros interesses de grupo e o próprio conjunto da sociedade, que se esforçam para manter um sistema que proteja a todos e a todas.

Se tais direitos foram elaborados e são aplicados dentro deste ideal universalista, não é possível negligenciar singularidades decorrentes de identidades de grupo como gênero e orientação sexual, mas tampouco não pode a universalidade ela própria ser desprezada.

A concretização dos direitos sociais passa por uma postura ativa dos poderes políticos eleitos (legislativo e executivo), na medida em que estes são os canais institucionais que reverberam a vontade popular majoritária e suas escolhas na definição das prioridades das 
políticas públicas que realizam direitos sociais.

O papel dos juízes e tribunais aqui é de certa deferência, na medida em que caberia a estes poderes políticos eleitos as escolhas primárias sobre o modelo de universalização e concretização dos direitos sociais, com base na vontade popular e na promoção do bem estar de todos/as. Ao mesmo tempo, são fatores da equação o grau de determinação da linguagem constitucional e o nível de interlocução entre maioria e grupos minoritários no âmbito do processo democrático.

Tratando-se especificamente de gênero, a igualdade entre homens e mulheres é uma decisão substantiva com foro constitucional, mas há divergências, mesmo dentro do próprio campo feminista, sobre qual a política pode realizar melhor isto, enfrentando aspectos androcêntricos.

Neste sentido, não é óbvia a escolha por um modelo de igualdade de gênero (chefe de família universal, cuidador/a universal), tratando-se se uma escolha política que transcende os parâmetros objetivos de atuação judicial, pois são limitadas as possibilidades de juízes e tribunais aferirem qual modelo encontra aceitação majoritária e atende ao respeito à singularidade.

Desta forma, seria necessário criar canais de comunicação com os "usuários do social", para que estes pudessem formular suas demandas e expor em público as características de suas singularidades, de modo a viabilizar uma execução dos direitos sociais prestacionais devidamente voltada para as necessidades dos grupos mencionados.

\section{REFERÊNCIAS}

BADINTER, Elizabeth. Um amor conquistado: o mito do amor materno. Tradução Waltensir Dutra. Rio de Janeiro: Nova Fronteira, 1985.

BARTHOLO, Letícia. Bolsa Família e relações de gênero: o que indicam as pesquisas nacionais. International Policy Centre for Inclusive Growth, [S.I.], n. 55, ago. 2016. Disponível em: <http://http://www.ipcundp.org/pub/port/PRB55PT_Bolsa_Familia_e_relacoes_de_genero.pdf $>$. Acesso em: $7 \mathrm{fev}$. 2019.

BRASIL. Câmara dos Deputados, 2017a. Comissão Especial PL 6.787/2016. Reforma Trabalhista. Disponível em: <http://www2.camara.leg.br/deputados/discursos-enotastaquigraficas/discursos-em-destaque/projeto-de-lei-no-6787-2016- 


\section{RFD}

reformatrabalhista/Reuniao\%200272-

17\%20de\%20120417\%20Dep\%20Rogeiro\%20Marinho.pdf >. Acesso em 7 fev. 2017.

BRASIL. Procuradoria Geral da República. Parecer nº 324/2018 - SFCONST/PGR na Ação Direta de Inconstitucionalidade 5.938/DF. Disponível em:

<http://portal.stf.jus.br/processos/downloadPeca.asp?id=15339307866\&ext=.pdf>. Acesso em 7 fev. 2019.

BRASIL. Lei no 8.213, de 24 de julho de 1991. Dispõe sobre os Planos de Benefícios da Previdência Social e dá outras providências. Diário Oficial [da] República Federativa do Brasil, Brasília, DF, 24 jan. 1991. Art. 1º. Disponível em:

<http://www.planalto.gov.br/ccivil_03/leis/L8213cons.htm>. Acesso em: 6 fev. 2019.

Agende ações em gênero, cidadania e desenvolvimento (Convenção sobre a

eliminação de todas as formas de discriminação contra a mulher). Adotada pela Assembleia Geral das Nações Unidas em 18.12.1979, entrou em vigor em 03.09.1981. Assinada pelo Brasil, com reservas, em 31.03.1981 e ratificada, com reservas, em 01.02.1984, entrou em vigor em nosso país em 02.03.1984. Em 22.06.1994 foi ratificada, sem reservas. Diário Oficial [da] República Federativa do Brasil, Brasília, DF, 23 jun. 1994. Disponível em: <http://www.agende.org.br/docs/File/convencoes/cedaw/docs/Convencao.pdf>. Acesso em: 6 fev. 2019.

. Decreto 9028/2017. Dispõe sobre a organização e o funcionamento do Conselho Nacional do Trabalho, e dá outras providências. Diário Oficial [da] República Federativa do Brasil, Brasília, DF, 4 set. 1995. Disponível em: <http:// http://www.planalto.gov.br/ccivil_03/_Ato2015-2018/2017/Decreto/D9028.htm\#art9 >. Acesso em: 6 fev. 2019.

. Lei no 10.836, de 9 de janeiro de 2004. Cria o Programa Bolsa Família e dá outras providências. Diário Oficial [da] República Federativa do Brasil, Brasília, DF, 9 jan. 2004. Disponível em: <http://www.planalto.gov.br/ccivil_03/_Ato20042006/2004/Lei/L10.836.htm>. Acesso em: 6 fev. 2019.

. Lei $n^{\circ} 13467 / 2017$. Altera a Consolidação das Leis do Trabalho (CLT), aprovada pelo Decreto-Lei no 5.452, de 1 o de maio de 1943, e as Leis nos 6.019, de 3 de janeiro de 1974, 8.036, de 11 de maio de 1990, e 8.212, de 24 de julho de 1991, a fim de adequar a legislação às novas relações de trabalho. Diário Oficial [da] República Federativa do Brasil, Brasília, DF, 4 set. 1995. Disponível em: <http:// http://www.planalto.gov.br/ccivil_03/_Ato2015-2018/2017/Lei/L13467.htm>. Acesso em 7 fev. 2017. 
. Decreto ${ }^{\circ} 5.209$ de 17 de setembro de 2004. Regulamenta a Lei no 10.836 , de 9 de janeiro de 2004, que cria o Programa Bolsa Família, e dá outras providências. Diário Oficial [da] República Federativa do Brasil, Brasília, DF, 17 set. 2004. Disponível em: <http://www.planalto.gov.br/ccivil_03/_Ato2004-2006/2004/Decreto/D5209.htm>. Acesso em: 6 fev. 2019.

. Medida Provisória $n^{\circ} 870$, de $1^{\circ}$ de janeiro de 2019. Estabelece a organização básica dos órgãos da Presidência da República e dos Ministérios. Diário Oficial [da] República Federativa do Brasil, Brasília, DF, 17 set. 2004. Disponível em: <http:// http://www.planalto.gov.br/ccivil_03/_Ato2019-2022/2019/Mpv/mpv870.htm>. Acesso em: 7 fev. 2019.

. Supremo Tribunal Federal. Ação Direta de Inconstitucionalidade número 5938. Relator: Ministro Alexandre de Moraes. Brasília, em julgamento. Disponível em: <http://portal.stf.jus.br/processos/detalhe.asp?incidente=5447065>. Acesso em 7 fev. 2019.

. Tribunal Regional do Trabalho da $3^{\text {a }}$ Região ( $8^{\mathrm{a}}$ Turma). Relator: Juiz José Miguel de Campos. Belo Horizonte, 26 de fevereiro de 2005. Disponível em: $<$ https://as1.trt3.jus.br/juris/detalhe.htm?conversationld=16805>. Acesso em 18 jan. 2013.

. Tribunal Regional do Trabalho da $5^{\mathrm{a}}$ Região (2a Turma). Processo 011640040.2006.5.05.0029 RO, ac. nº 028135/2007. Relator: Desembargador Cláudio Brandão. Salvador, 02 de outubro de 2007. Disponível em:

<http://www.trt5.jus.br/default.asp?pagina=acordaoPesquisaAvancada\&arrayCodDesembar gador $=49559,10814,9492,18491,22359,20895,6582,48781,19838,2250,19846,10750,539$ 71,22367,9476,19820,10326,4768,66429,48501,10393,9689,9727,10784,57314,14801,71 55,9956,4300>. Acesso em: 19 jan. 2013.

. Tribunal Superior do Trabalho (8 Turma). AIRR - 11751-62.2015.5.01.0015. Relatora: Min. Maria Cristina Irigoyen Peduzzi. Brasília, 14 de novembro de 2018.

. Tribunal Superior do Trabalho (1 $1^{\text {a }}$ Turma). RR - 154000-93.2000.5.19.0004. Relator: Min. Lelio Bentes Corrêa. Brasília, 05 de outubro de 2005. . Tribunal Superior do Trabalho (2a Turma). RR - 101900-52.2004.5.05.0024. Relator: Min. José Simpliciano Fontes de F. Fernandes. Brasília, 15 de maio de 2009.

BAUTISTA, Myriam. Domènech fala sobre experiência de Sin Permiso. Carta Maior, Bogotá, 17 jun. 2009. Disponível em: 
<http://www.cartamaior.com.br/templates/materialmprimir.cfm?materia_id=16036>.

Acesso em: 6 fev. 2019.

DONZELOT, Jacques. A polícia das famílias. Tradução M. T. da Costa Albuquerque. Rio de Janeiro: Graal, 2001.

ESPING-ANDERSEN, Gosta. The three worlds of welfare capitalism. Cambridge: Polity Press, 1990.

FRASER, Nancy. Gender equity and the Welfare State: a postindustrial thought experiment. In: BENHABIB, Seyla (Org.). Democracy and Difference. Princeton: Princeton University Press, 1996.

FUNDO DE DESENVOLVIMENTO DAS NAÇÕES UNIDAS PARA A MULHER (United Nations Entity for Gender Equality and the Empowerment of Women): Relatório "Progress of the World's Women" (Progresso das Mulheres do Mundo) 2011-2012. Disponível em: $<$ http://progress.unwomen.org/pdfs/EN-Report-Progress.pdf>. Acesso em: 6 fev. 2019.

IBRAHIM, Fábio Zambitte. Curso de direito previdenciário. Niterói: Impetus, 2010.

LAVINAS, Maria Helena de Morais. Direito previdenciário para donas de casa versus universalidade da proteção social no Brasil. Contribuição de Marcelo Nicoll. Disponível em: $<$ http://www.ie.ufrj.br/aparte/pdfs/lavinas_direito_prev_donas_de_casa.pdf>. Acesso em: 6 fev. 2019.

LUCAS, Luciane; HOFF, Tânia. Formas sutis de dominação hierarquizada: Corpo e feminização da pobreza. Ex aequo, Vila Franca de Xira, n. 17, 2008. Disponível em: $<$ http://www.scielo.gpeari.mctes.pt/scielo.php?script=sci_arttext\&pid=S087455602008000100009\&lng=pt\&nrm=iso >. Acesso em: 6 fev. 2019.

NAÇÕES UNIDAS (ONU). CEPAL. O bônus na mira. Aporte e carga para as mulheres. Observatorio de igualdad de género de América Latina y el Caribe. Informe anual 2012. Impresso nas Nações Unidas, Santiago do Chile, 2013. p. 49-73. ISSN 2307-5627.

Disponível em: <https://repositorio.cepal.org/bitstream/handle/11362/35446/1/S2013192_pt.pdf>. Acesso em: 6 fev. 2019.

NUSSBAUM, Martha C. Sex and social justice. Nova Iorque: Oxford University Press, 1999. 
PESSANHA, Érica. A eficácia dos direitos sociais prestacionais. Revista da Faculdade de Direito de Campos, [S.I.], ano VII, n. 8, jun. 2006. Disponível em:

$<$ http://fdc.br/Arquivos/Mestrado/Revistas/Revista08/Discente/Erica.pdf>. Acesso em: 6 fev. 2019.

PULIDO, Carlos Bernal. Fundamento, conceito e estrutura dos direitos sociais: uma crítica a "existem direitos sociais?" de Fernando Atria. In: SOUZA NETO, Cláudio Pereira de; SARMENTO, Daniel (Orgs.). Direitos sociais: fundamentos, judicialização e direitos sociais em espécie. Rio de Janeiro: Lumen Juris, 2008.

ROSANVALLON, Pierre. La sociedad de los iguales. Tradução para o espanhol de Maria Pons. Barcelona: RBA Libros, 2012.

SANCHES, Mariana. O Bolsa Família e a revolução feminista no sertão. Revista Marie Claire, [S.I.], de 21 nov. 2012. Seção Mulheres do Mundo. Disponível em: <http:// https://revistamarieclaire.globo.com/Mulheres-do-Mundo/noticia/2012/11/o-bolsa-familia-erevolucao-feminista-no-sertao.html>. Acesso em: 7 fev. 2019.

SANTOS, Tânia Steren dos. Gênero e políticas sociais: novos condicionamentos sobre a estrutura familiar. Revista SER Socia, [S.I.], v. 10, n. 22, jun./jul. 2008. Disponível em: <http://seer.bce.unb.br/index.php/SER_Social/article/view/23/16>. Acesso em: 10 mar. 2013.

SARMENTO, Daniel. Direitos fundamentais e relações privadas. Rio de Janeiro: Lumen Juris, 2004.

SILVA, Maryland Medeiros da; SILVA, Paula Isabel Nóbrega Introine. A gestante e o meio ambiente laboral: uma análise da Lei 13467/2017 à luz do retrocesso social. In: CONGRESSO NACIONAL DO CONPEDI SÃO LUÍS, 26., 2017, São Luís. Disponível em: $<$ https://www.conpedi.org.br/publicacoes/27ixgmd9/6mb1v344/51K0eqrj6875Hp4c.pdf>. Acesso em: 7 fev. 2019.

TORRES, Ricardo Lobo. O mínimo existencial como conteúdo essencial dos direitos fundamentais. In: SOUZA NETO, Cláudio Pereira de; SARMENTO, Daniel (Orgs.). Direitos sociais: fundamentos, judicialização e direitos sociais em espécie. Rio de Janeiro: Lumen Juris, 2008.

ZAGREBELSKY, Gustavo. El derecho dúctil: Ley, Derechos, Justicia. Madrid: Trotta, 2003. 